\title{
WHAT'S BEEN HAPPENING TO AGGREGATE CONCENTRATION IN THE UNITED \\ STATES? (AND SHOULD WE CARE?)
}

\author{
Lawrence J. White \\ Stern School of Business \\ New York University \\ lwhite@stern.nyu.edu \\ Draft: $12 / 11 / 01$ \\ Please do not quote or cite \\ without the permission of the author
}

Comments welcomed

\begin{abstract}
In this paper I assemble and array two rarely used data sets to measure the extent of aggregate concentration -- the share of national economic activity accounted for by the largest $\mathbf{X}$ companies -- in the U.S. in the 1980s and 1990s. The data show clearly that, despite the substantial merger wave of the 1980s and the far larger wave of the 1990s, aggregate concentration declined in the 1980s and the early 1990s. Aggregate concentration increased after the mid 1990s, but the levels at the end of the decade were still at or below the levels of the late 1980s or early 1990s. The average size of firm did increase, however, and the relative importance of the larger size classes of firms increased generally. Gini coefficients computed for employment shares and payroll shares of companies showed moderate but steady increases from 1988 through 1998. In the conclusion of the paper I offer some tentative hypotheses for explaining these patterns.
\end{abstract}

JEL classification numbers: L11; L19

Key words: aggregate concentration; mergers; size distribution of firms 


\title{
WHAT'S BEEN HAPPENING TO AGGREGATE CONCENTRATION IN THE UNITED STATES? (AND SHOULD WE CARE?)
}

\author{
Lawrence J. White \\ Stern School of Business \\ New York University \\ lwhite@stern.nyu.edu
}

Draft: $12 / 3 / 01$

L. Introduction

Whenever the U.S. economy experiences a major wave of large mergers, as it clearly did in the 1990 s and to a lesser extent in the 1980s, a natural question to consider is the structural consequences for the U.S. economy: Are the mergers significantly changing the size-distribution of large firms and thereby causing the largest firms in the economy to grow relative to the overall size of the economy? And if that were so and if the effects were persistent, is this a matter of economic or social concern? Might we soon arrive at the outcome suggested by the title of a 1976 New York magazine article (Tobias 1976): "March 3, 1998: The Day They Couldn't Fill the FORTUNE 500"?

This article will address these questions, employing two rarely used data sets for the 1980s and 1990s. As a shorthand, the share of some national economic aggregate that is accounted for by the largest $\mathbf{X}_{\square}$ firms in the economy is frequently described as a measure of "aggregate concentratign". ${ }^{1}$ Thus, this article will be about aggregate concentration in the U.S. in the 1980s and 1990s. ${ }^{2}$

\footnotetext{
${ }^{1}$ As will be discussed below, the measurement of aggregate concentration, as well the questions that the measurement addresses, are separate and separable from the more familiar issues and measurement concerning seller concentration and the exercise of market power in specific markets.

${ }^{2}$ Summaries of measurements for earlier periods can be found in Scherer (1970, 1980), White (1981), Golbe and White (1988), and Scherer and Ross (1990); see also Pryor (forthcoming (b)). Among the earliest efforts to measure aggregate concentration was that of Berle and Means (1932), who measured the share of all non-financial firms' assets that were accounted for by the largest 200 companies, for the years 1909 through 1929. It is noteworthy that Berle and Means made their measurements shortly after the merger wave of the 1920s and that Scherer (1970) extensively reviewed the extant studies shortly after the merger wave of the 1960s.
} 
To help guide the discussion that follows, I will preview my findings: The data show clearly an strongly that -- despite the recent wave of mergers -- aggregate concentration declined during the 1980s and early 1990s and then generally increased after the mid 1990s, but the levels at the end of the decade remained at or below the levels of the late 1980s or early 1990s. However, the average size of firm increased steadily from 1988 onward, as did the relative importance of the larger size classes of firms (even though the shares of the giants have not increased), and the size distribution of firms became slightly more skewed toward larger firms.

In the conclusion I will offer some tentative hypotheses to explain these patterns. 


\section{The Merger Wave}

Though the merger wave of the 1980s and 1990s is not the focus of this article, ${ }^{3}$ a brief presentation of those data will be worthwhile, to set the stage.

Annual data on economy-wide mergers and acquisitions (M\&As) can be found in two sources: Mergerstat Review, and Mergers \& Acquisitions magazine. Both sources track "large" (based on purchase price) M\&As, compiled from business and financial news reports; the merger of Nora's Coffee Shop with Joe's Gasoline Station ("Eat Here and Get Gas!") will not be included in either data set. ${ }^{4}$ Both sources offer data on the annual number of M\&As and on the annual value -aggregated purchase prices -- of the M\&As. For both sources the value series is even less complete than the numbers series, because some acquisitions -- involving companies that are not publicly traded -- may not yield publicly disclosed terms of the transaction; because these non-public transactions tend to be the smaller ones, however, this incompleteness is not as serious as it might otherwise seem to be.

Figure 1 shows the estimates of the annual number of large M\&As from both sources of data; Figure 2 shows the annual M\&A value data. The data for the annual numbefof large mergers in Figure 1 show a clear wave in the 1990s that peaked in 1999 or $2000 ;^{5}$ the Mergers \& Acquisitions data also show a smaller rise in the 1980s, while the Mergerstat data show no such rise in the 1980s but show that the merger wave of the late 1960s and early 1970s was numerically

${ }^{3}$ For a discussion of the current wave, see Black (2000) and Pryor(forthcoming (a)); for discussions of waves up to the early 1980s, see Golbe and White $(1988 ; 1993)$.

${ }^{4}$ See the appendix for a discussion of the two sources' size criteria.

${ }^{5}$ Preliminary data for 2001 indicate that merger activity will be substantially reduced for this year. 
substantial. $^{6}$

The data from both sources are more consistent for the annual value-of-mergers series in Figure 2: There was a modest wave in the mid 1980s that peaked in the late 1980s and then a far more sizable wave that began in the early 1990s.

Some deflating of these data is warranted, however, because the U.S. economy grew substantially in nominal and real terms during the four decades covered by the data. There are two candidates for deflating the annual numbers of mergers: annual real GDP, since the economy was growing and transactions of all kinds could be expected to increase as well; and the annual aggregate number of corporations in the economy, since the large companies that are buying and being bought in these M\&A series are overwhelmingly corporations. ${ }^{7}$ For the annual value of M\&As, there are three candidates for deflation: just the annual GDP deflator, to correct for the general increase in prices in the U.S. economy; annual nominal GDP, to correct for inflation and the larger real ecgnomy over time; and an annual measure of the aggregate value of all publicly traded corporations, ${ }^{8}$ since these values are the base from which successful M\&A transactions must be negotiated.

Figures 3 and 4 show the deflated M\&A numbers series (converted to index numbers, with $1980=100$ ); Figures 5, 6, and 7 show the deflated M\&A value series (again converted to index numbers with $1980=100$ ). The Figures $3-6$ tell the same fundamental story as the undeflated Figures 1 - 2. Figure 7, however, which deflates the merger value series by the aggregate market

${ }^{6}$ Part of this earlier importance may be an illusion, however, since, as is described in the Appendix, Mergerstat used lower minimum size criteria for the inclusion of transactions in its M\&A series prior to 1989 .

${ }^{7}$ In the calculations described below, we subtract the small "S" corporations from the annual aggregate number of corporations.

${ }^{8}$ The data from the Federal Reserve's "flow of funds" tabulations are used. 
value of traded companies, shows that by this measure the merger wave of the 1990s was no bigger than the wave of the 1980s. ${ }^{9}$

In any event, regardless of series used, whether deflated or not, the data indicate that the U.S. economy experienced a modest merger wave during the 1980s and another wave in the 1990s that, except when merger values are deflated by aggregate stock market value, was far more substantial.

${ }^{9}$ There is, however, a causality issue: Were the market values of traded companies inflated by expectations of takeovers? 


\section{Measuring Aggregate Concentration: Why, How, and Earlier Estimates}

\section{A. Why measure aggregate concentration?}

The political/social concerns about the economic, political, and social power that might be a consequence of the presence and relative growth of large companies in the U.S. economy have a long history. They extend back at least to the populist movement of the late nineteenth century and arguably back even to Jefferson's support for and concerns about yeomen farmers.

One manifestation of the populist concern about the economic power of large companies was the U.S. antitrust laws, notably the Sherman Act of 1890, the Clayton Act of 1914, and the Federal Trade Commission Act of 1914. The populist concern about the wider social/political influence and power of large and growing companies found no similar specific national legislative expression in the nineteenth century. One state-level manifestation, however, was the universal prohibition by the states on interstate branching by banks and the limitations by most states on intra-state banking. Many states, especially those that were heavily agricultural, even limited their banks to a single lofation ("unit banking"). The intent clearly was that banks should be kept small and locally focused. ${ }^{10}$

The populist concern about the growth of large corporations and the concomitant decrease in the relative importance of small enterprises finally found its national expression in the New Deal legislation of the 1930s, following the stock market crash of 1929-1933 and the onset of the Great Depression. The manifestations were primarily in measures to aid and preserve small enterprises. The National Industrial Recovery Act of 1933 had this intent, with the National Recovery Administration (NRA) subsequently permitting nearly a thousand industry groups to develop "codes of fair competition" that were intended to discourage price cutting and other aggressive

\footnotetext{
${ }^{10}$ For further discussions, see White $(1993,1995)$.
} 
behaviors so that smaller enterprises could survive alongside larger ones. The Robinson-Patman Act of 1936 amended the Clayton Act to strengthen its prohibitions on price discrimination, with the intention of helping small businesses, especially small retailers, by preventing their larger rivals from receiving lower prices from suppliers. The Miller-Tydings Resale Price Maintenance Act of 1937, which permitted the states to authorize resale price maintenance ("fair trade"), was championed by small retailers (especially pharmacists) that wished to limit the price cutting of their larger (chain-store) rivals. Even the Agricultural Adjustment Acts (AAA) of 1933 and 1936 had the preservation of small ("family") farms as a major goal.

After World War II the Eisenhower Administration in 1953 established the Small Business Administration, as an agency to aid and encourage small businesses, and various legislative acts, such as authorizations for Defense Department procurement, included "set-asides" for small businesses. Periodic legislative acts to support U.S. agriculture have had the continued goal of supporting the (small) family farm.

It is clear, then, that the political/social concerns about the absolute and relative sizes of businesses in the U.S. economy have a long history. Though their recent manifestations have primarily focused on concerns about small businesses, the concern about large companies has also been present. In the late 1970s, for example, as political concerns about a new wave of mergers heightened, legislation that would have limited mergers by large firms was seriously considered by the Congress before being dropped. And in the Riegle-Neale Interstate Branching Act of 1994, which finally provided federal endorsement for interstate branching, there nevertheless were (and still are) ceilings on the fraction of a state's bank deposits that any single bank could account for.

Even aside from any populist feelings that might trigger concerns about large companies, it seems clear that the feel and fabric of an economy where, say, only 100 companies -- or even 1,000 -- accounted for all or virtually all of economic activity would be quite different from one in which economic activity was substantially more widely dispersed. These differences need not be the 
consequence of the exercise of market power by the large companies in individual markets. After all, if all 100 of these companies had roughly equal presences in all relevant markets, the measured levels of seller concentrations in these markets would easily satisfy the structural pre-conditions for perfect or near-perfect competition. ${ }^{11}$ Nevertheless, with, say, only 100 companies accounting for virtually all of private sector GDP, the average number of employees per company would be approximately one million, and the average value added per company would be $\$ 80$ billion. The landscape for employment opportunities or for the funding of new ideas, for example, would be quite different from that found in a less concentrated economy. Even if there were 1,000 economywide companies and the per-company magnitudes were only a tenth as large as just mentioned, we would still be describing a very different landscape than (as we will demonstrate) is present in today's U.S. economy.

Further, even if one were unsure whether aggregate concentration could be a problem (and if so, at which levels), nevertheless information about changes in aggregate concentration level could be useful, especially if they were to show no change or a decrease (thus indicating that, even if one believed that there might be a problem, it wasn't getting any worse).

\section{B. How to measure aggregate concentration}

If one is concerned about the relative share of economic activity of large companies, then surely the aggregated value added of the companies is the best all-around measure. A further advantage is that value added is unambiguously comparable across all firms, regardless of the nature of their business.

Some other candidate measures -- employment, aggregate wages or payroll, or profits -- are

11 The huge number of multi-market contacts that this structure would imply might weaken substantially the competitive behavior that the individual market seller concentrations would otherwise imply. For discussions of the potential and actual influence of multi-market contacts, see Feinberg (1985), Rhoades and Heggestad (1985), and Bernheim and Whinston (1990). 
simply components (directly or indirectly ${ }^{12}$ ) of value added. ${ }^{13}$ Another candidate measure, aggregate sales revenue (which was popularized by its use as the criteria for specifying Fortune magazine's "Fortune 500"), presents obvious problems of double-counting and the related problem of a sales measure's exclusion of the extent of vertical integration of the enterprise; thus, vertical mergers would yield little or no apparent increase in sales and therefore no change in relative importance of the merged entity, despite its expanded economic activity. ${ }^{14}$

Further, the "sales revenue" concept for financial institutions is less well defined. Should the concept include the securities sales of a brokerage firm on behalf of its customers? Should the concept include the firm's securities sales from its own portfolio? Both? Neither? In practice, neither category is reported as sales revenue. Instead, financial firms register as revenue their interest and fee income plus any gains from their trading operations. This revenue concept seems appropriate for comparisons with a non-financial firm. But the employees of financial firms primarily think of the sizes of their companies in terms of assets -- which brings us to another candidate measure.

A firm's assets ${ }^{15}$ as the basis for an aggregate concentration measurement presents at least

12 I.e., employment is an indirect component, since it is employment multiplied by the compensation per worker that yields aggregate labor income, which is a direct component of value added.

13 Also, a company's reported pre-tax profits can be affected by the vagaries of allowed depreciation and amortization rates -- which can vary across firms depending on the types of assets in which they have invested -- and its post-tax profits can be further affected by corporate tax rates (which again can vary across firms depending on tax brackets and any special provisions in the tax code).

14 Retail firms with relatively thin value-added margins would be over-represented by a salesbased measure; "upstream" firms with greater value-added relative to sales would be underrepresented.

15 Like employment, assets would be an indirect component of a firm's value added; when multiplied by the profit rate on those assets, the firm's profits -- a direct component of value added - would be obtained. 
three problems: First, if financial intermediaries, such as banks, insurance companies, and mutual funds are included, there is substantial double-counting, since the assets of these intermediaries largely consist of the liabilities of the enterprises to which they have lent or in which they have invested, with those liabilities in turn having been used to fund the assets of those enterprises.

Second, the presence of two alternative accounting treatments for M\&As can mean substantially different levels of assets that would appear on an acquiring company's balance sheet, solely because of the acquirer's choice of accounting treatment. Pooling, where the assets of the acquired company are simply transferred to the acquiring company's balance sheet at their premerger balance-sheet values, would mean relatively lower post-merger asset values; purchase accounting, where an additional goodwill asset is created and entered on the acquiring company's balance sheet, to reflect the difference between the purchase price and the pre-merger net asset (balance-sheet) value of the acquired company, would mean relatively higher post-merger asset values. Thus, reported asset values could vary substantially, depending on which accounting treatment was chosen in for otherwise identical mergers.

Third, changes over time in accounting and tax treatment of asset depreciation, amortization, and write-offs, as well as changes in the expensing-versus-writeoff treatment of various categories of costs, could arbitrarily affect reported asset values.

Despite value added's superiority as an all-around measure of relative importance, one offsetting argument should be entered. The political process does place a great deal of emphasis on employment -- "jobs" and job creation and losses -- as well as on wage income. Accordingly, a focus on the employment share and on the aggregate wages (payroll) share of large companies may well be an appropriate runner-up measure to value added.

\section{Actual measures.}

Unfortunately, despite the superiority of value added for measuring large companies' 
relative importance, value-added data are not widely collected on a systematic basis at the company level. The only exception is the Census Bureau's Census of Manufactures' reporting of the relative value added of the 50,100, 150, and 200 largest manufacturing companies (against the base of all manufacturing enterprises) for the economic centw years beginning in 1947 and continuing through the most recently available census, 1997. ${ }^{16}$ But manufacturing, of course, has never constituted the entire private sector or even as myet as a third of the private sector, and its relative importance has declined over these 50 years. ${ }^{17}$ Consequently, these value added data for manufacturing, though correct in intent and concept, are sorely incomplete as an economy-wide measure of aggregate concentration.

In the absence of company-level value-added data for anything beyond manufacturing, efforts to measure aggregate concentration have focused on employment, profits, and non-financial firms' assets. Employment and profits data have been drawn from the Fortune lists. The "Fortune 500" lists, first published in 1955 (covering firms' 1954 data), were based on fales rankings and initially included only "industrial" (i.e., manufacturing and mining) companies. ${ }^{18}$ However, their reach was expanded sufficiently in the early 1970s so that economy-wide aggregate concentration measures of employment and profits could be compiled for the 1970s on a reasonably consistent year-to-year basis (White 1981). A drawback, however, was that the company data for employment and after-tax profits reported by Fortune were based on consolidated company reports and thus

16 The economic census years have been 1947, 1954, 1958, 1963, 1967, 1972, 1977, 1982, 1987 , 1992, and 1997. In addition, value-added aggregate concentration measures were offered in the Census Bureau's Annual Survey of Manufactures for the years 1962, 1966, 1970, and 1976.

17 In 1947 manufacturing constituted $30.8 \%$ of U.S. private-sector GDP. It hit a post-war percentage high in 1955 , at $33.1 \%$ (just shy of a third), and has been declining (relatively) ever since. In 1999 the manufacturing sector constituted 20.5\% of non-governmental GDP.

18 This restriction meant that large utilities, including AT\&T, banks, insurance companies, railroads and airlines, and service companies were excluded from the lists. 
included their non-U.S. operations. Accordingly, the aggregate concentration measure -- the fraction of U.S. private sector employment (or profits) that was accounted for by the largest $\mathbf{X}$ companies -- involved a numerator that included some non-U.S. employment (or profits); and, so long as the large firms were expanding their non-U.S. operations at a different rate than their U.S. activities, year-to-year comparisons were subject to error. ${ }^{19}$ Also, the after-tax profit data were subject to the vagaries noted above. Finally, Fortune changed its coverage sufficiently in the early 1980s so that measurements for these years were not comparable with the measurements of the 1970s.

Data for the 50, 100, 150, and 200 largest non-financial companies' assets were compiled by the Federal Trade Commission and were available from 1958 to 1988. But, by excluding financial firms they were necessarily incomplete, as well as embodying the other drawbacks of assets measures.

\section{What did the earlier measurements indicate?}

The data just described clearly had substantial imperfections. Still, even with those imperfections, what did the data indicate as to the levels and changes in aggregate concentration?

The cleanest data, as well as longest comparable series, has been the Bureau of the Census' value-added data for manufacturing for the economic census years (plus a few additional years) between 1947 and 1997. These data are presented in Table 1. As is indicated, they show a rise in manufacturing aggregate concentration between 1947 and 1954, a far more gradual rise for the next three decades, and then a decline in the 1990s. By 1997 the manufacturing aggregate concentration

\footnotetext{
19 Also, the Fortune lists exclude non-U.S. firms that have U.S. operations. Though less serious in the 1970s and before, this became a more serious issue in the 1980s and 1990s; for example, when Daimler absorbed Chrysler in 1998, Chrysler disappeared from the Fortune list, while Daimler-Chrysler (because it is not headquartered in the U.S.) did not replace Chrysler on the list. The same phenomenon occurred when BP absorbed Amoco in 1998.
} 
levels were at the levels of 1963 . But, of course, manufacturing was only a fraction of the overall private sector -- $30.8 \%$ of private-sector GDP in 1947 , rising to a peak of $33.1 \%$ in 1955 , and falling to $20.5 \%$ in 1999 .

The next longest data series was the FTC's non-financial corporations' assets. ${ }^{20}$ As shown in Table 2, these data indicate a modest decline in aggregate concentration between the late 1950s and the late 1970s and then a steeper decline in the 1980s.

Finally for more comprehensive (but shorter) economy-wide data (drawn from economywide Fortune lists) White (1981) showed that during the 1970s aggregate concentration -- based on both employment and corporate profits -- was relatively unchanged or may have declined modestly. These data are shown in Table 3.

In sum, the limited data previously collected indicates no net change in aggregate concentration (measured by value added) in manufacturing since the early 1960s, a decline in aggregate concentration (measured by assets) in the non-financial sector between the late 1950s and the late 1980s, and stability or a modest decline in economy-wide aggregate concentration (as measured by employment and by profits) in the 1970s.

${ }^{20}$ This series has been cited and described by Golbe and White (1988), Ginsberg (1986), and Yellen (1998). 


\section{Aggregate Concentration in the 1980s and 1990s}

With this background we can now discuss and present the new data that were gathered specially for this paper. First, though, let us dispel any lingering doubts as to whether somehow the U.S. economy has reached a skewed structural level approximating that 1976 New York magazine article's title. The 2001 Fortune list (covering data for the 1,000 largest companies across all sectors of the U.S. economy for 2f90, ranked by sales revenue) had no trouble finding 1,000 large companies to fill out its list; ${ }^{21}$ the 1,000 th company was the Amica Mutual Insurance Company, with revenues in 2000 of $\$ 1.2$ billion, $\$ 3.0$ billion in assets, and 3,316 employees. (The largest company by revenue size was Exxon Mobil, with $\$ 210.4$ billion in revenue; the largest company by assets was Citigroup, which had $\$ 902.2$ billion in assets.)

More generally, the U.S. in 2000 had 5.5 million cerporations, 2.0 million partnerships, and an estimated 17.7 million non-farm sole proprietorships. ${ }^{22}$ These numbers were up from 1980 numbers of 2.7 million corporations, 1.4 million partnerships, and 9.7 million non-farm sole proprietorships. $^{23}$ An expanding U.S. economy continues to be populated by an ever-rising number of enterprises of all kinds.

${ }^{21}$ To be fair, the 1976 article (with tongue in cheek) did not quite predict that there would be fewer than 500 firms in total in the U.S. economy in 1998. "There were more than 479 companies in the world [in 1997]... There were still tens of thousands of firms that ranged from one-man shops up to what once would have been considered a fairly good-sized company. But the gap between these and the 479 giants was enormous. It would have looked silly to put even a company with $\$ 248$ million in assets on the list, when the next largest ... -- number 479 -- had assets of nearly $\$ 7$ billion" (Tobias 1976).

22 These data are derived from IRS Statistics of Income data; the 2000 non-farm sole proprietorship number was extrapolated from the actual 1998 and 1999 data. In addition, there were 1.8 million farm sole proprietorships in 2000.

${ }^{23}$ There were also 2.5 million farm sole proprietorships in 1980. 
We now turn to our new data. Our data come from two sources: a relatively new annual data series encompassing employment and aggregate wages (payroll), which has been compiled by the Bureau of the Census; and the longer-standing annual "500" lists that have been compiled by Forbes magazine. We will discuss each in turn.

\section{A. The Bureau of the Census employment and payroll data.}

The Bureau of the Census has developed a publicly available annual series, "Statistics of U.S. Business", that enumerates the numbers of firms, numbers of establishments, employment, payroll, and sales receipts, drawn from company-level information on companies' U.S. operations. The data cover nearly all of the private-sector economy and are disaggregated into major one-digit SIC (through 1997) or two-digit NAICS (beginning in 1998) sectors. The series currently covers the years 1988-1998 (with 1999 to be released before the end of 2001). Most important for our purposes, the data are grouped into company-size categories based on a company's number of employees. Thus, there are company (employee) size categories of 0-4, 5-9, 10-19, 20-99, 100-499, and 500-and-above employees. For some years the size categories are finer, and for 1992 and 1998 the economy-wide employee size categories also extend to -550-999, 1,000-1,4999, 1,500-2,499, 2,500-4,999, 5,000-9,999, and 10,000-and-above employees. ${ }^{24}$

At this author's request the Bureau of the Census compiled the data for the numbers of firms, employment, and payroll for all years (i.e., 1988 - 1998) and for all of the coarse sectors into the complete range of employee size categories that extend to 10,000-and-above employees; in addition, the Bureau of the Census specially compiled the employment and payroll aggregates for the largest 100, 500, and 1,000 economy-wide companies, for each year.

24 These data can be found at http://www.census.gov/epcd/www/smallbus.html and at http://www.sba.gov/advo/stats/data.html. The data are described at greater length in Armington (1998), Robb (1999, 2000), and Kwoka and White (2001). 
Unfortunately, the data are not perfect. First, they cover only eleven years. Second, they cover only employment and payrel, not value added. Third, their coverage is not quite complete. They exclude the self-employed; ${ }^{25}$ farms; railroads; the U.S. Postal Service; households (e.g., as employers of domestic workers); and large pension, health, and welfare funds. They do, however, include non-profit enterprises generally.

Despite these drawbacks, the data are more comprehensive than most other measures, they are consistent from year to year, and they exclude non-U.S. operations while including the U.S. operations of non-U.S. companies. ${ }^{26}$ Also, these are the first-ever data to allow payroll information to be used for economy-wide aggregate concentration measurements. These are large pluses for a data set in an area that is as plagued by poor data as is the area of aggregate concentration.

Table 4 shows the total number of companies, their total employment and payroll, and their average employment and payroll size for 1988-1998. As can be seen, the total number of companies and their employment and payrolls grew over these eleven years. The average employment size of companies grew; their average payroll grew even faster (as would be expected in an era of rising wages).

Table 5 shows the economy-wide aggregate concentration measures of employment and of payroll for the largest 100, 500, and 1,000 U.S. companies and for all U.S. companies with 10,000 or more employees for the years 1988-1998. For the employment measure (Panel A), aggregate concentration for the largest 100, 500, and 1,000 companies clearly declined through 1995 and then

25 The Bureau of the Census describes the coverage as encompassing "employer firms". For 1998 the Census Bureau lists 5,579,177 "employer firms" that had 108,117,731 employees. It lists 15,708,727 "nonemployer firms". Many of these latter enterprises represent part-time efforts by individuals who have full-time employment elsewhere, in an "employer firm", so the full-time equivalent employment of these "non-employer firms" is substantially smaller than their aggregate number indicates.

${ }^{26}$ This restriction limits the non-U.S. company's apparent importance. But, short of compiling a global aggregate concentration measure, there is no satisfactory way of handling this issue. 
rose, so that by 1998 their levels were approaching or were at those of the late 1980s.

For the payroll measure (Panel B of Table 5), the decline in aggregate concentration through the middle 1990s was more pronounced than was true for the employment measure. Despite some increases after 1995 or 1996, aggregate concentration levels in 1998 were lower than they had been in 1988 for the 100,500 , and 1,000 largest companies.

The data from Table 5, then, are clear: Economy-wide aggregate concentration levels for the largest 100, 500, and 1,000 companies, whether measured by employment or by payroll, declined from 1988 through the mid 1990s and then rose, but by 1998 they were either still below or just equal to their 1988 levels.

Another feature of the employment data is worth noting. Kwoka and White (2001) found that the fraction of employment accounted for by "small firms" -- firms with fewer than 100 employees or fewer than 500 employees -- declined between 1988 and 1996. These data are reproduced and updated in Table 6, and the payroll data are added as well; the decline also encompassed payroll shares and continued in 1997 and 1998. Since the smallest firms were losing their employment shares, while the largest 100, 500, and 1,000 companies were either losing employment shares or just keeping pace, the necessary implication is the firms in between -firms that were larger than the smallest firms but smaller than the giants ${ }^{27}$-- were the net gainers.

Tables 7 and 8 shed further light on these size distribution questions. Panel A of Table 7 shows the aggregate numbers of companies in the various size classes; all size classes showed absolute growth in the numbers of companies throughout the period. Panel B shows their relative distribution. The smaller size classes tended to be relatively stable or to decline slightly; the larger size classes (100-499 employees, and larger) tended to grow in relative numbers.

The size classes' shares of employment and payroll are shown in Table 8. Panel A shows

\footnotetext{
${ }^{27}$ In 1998 the 100 largest companies averaged 116,705 employees; the largest 500 averaged 43,438 employees; and the largest 1,000 companies averaged 29,268 employees.
} 
that the smaller size classes -- those at or below 20-99 employees -- experienced declines in their shares of employment of the 1988-1998 period. The 100-499 employee size class was relatively stable over these years. The next larger size classes -- those between 500-999 employees and 2,5004,999 employees -- experienced a rise in employment shares through the mid 1990s and then a modest decline. Finally, the largest size classes -- 5,000-9,999 employees and 10,000+ employees - showed a modest rise through the mid 1990s and then a sharper rise in the late 1990s.

Panel B of Table 8 shows the payroll shares. The pattern for payroll shares is similar to that of employment shares, except that the payroll share of the largest size group declined through the mid 1990s before rising in 1998 to a level that was only slightly higher than that of 1988.

These employment and payroll share patterns raise the possibility of something more than just the increases in the average employee size and payroll size of companies shown in Table 4. The size distribution of companies may have become more skewed toward larger firms, despite the decline or stability of aggregate concentration among the giants shown in Table 6. One way of investigating this possibility is to compute Gini coefficients for cumulative employment shares relative to cumulative epmpany size shares and for cumulative payroll shares relative to cumulative company size shares. ${ }^{28}$ These are shown in Table 9. They indicate a small but steady growth of

${ }^{28}$ The Gini coefficient is a measure of the inequality of the distribution of some variable across a population. It is the following ratio: the area between the Lorenz curve (which plots the cumulative fractional share of the variable against the cumulative fractional share of the population) and the diagonal (which represents perfect equality of distribution of the variable), divided by the area of the triangle beneath the diagonal (which is 0.5 ). A Gini coefficient takes the value 0.0 for complete equality across the population and 1.0 for complete inequality (i.e., n-1 members of the population have nothing, and the nth member has the entire amount). For the size category data that are available in Tables 6 and 7, the Gini coefficient is calculated as follows:

$$
\mathrm{G}=\underset{\mathrm{i}=1}{\mathrm{~m}-1}\left(\mathrm{~F}_{\mathrm{i}} \mathrm{H}_{\mathrm{i}+1}-\mathrm{F}_{\mathrm{i}+1} \mathrm{H}_{\mathrm{i}}\right)
$$

where $\mathrm{F}_{\mathrm{i}}$ represents the cumulative population (i.e., company) share and $\mathrm{H}_{\mathrm{i}}$ represents the cumulative employment (or payroll) share for size category i among the $\mathrm{m}(=11)$ size categories. 
Gini coefficients for both categories. ${ }^{29}$ Thus, despite the decline or stability of the economy-wide aggregate concentration measures, there was a mild tendency for the firms in the larger size categories in the economy (though not the giants) to be growing relatively more important.

The data in Tables 10 and 11 provide further information on how the trends in the major sectors may have been affecting the economy-wide trends, by examining the employment and payroll shares for companies with 10,000-and-above employees. These sectoral data are not additively comparable to the economy-wide data, because a company with 10,000-and-above economy-wide employees might show up in none, one, or more than one of the sectors of Tables 10 and 11, depending on that company's employee distribution across sectors. Nevertheless, the tables provide a sense of the underlying trends within these sectors, at least through 1997 (since the 1998 change in classification system makes comparisons more problematic for some sectors). As can be seen, the employment shares of the 10,000-and-above companies fell in mining, construction, manufacturing, and transportation-communications-utilities. They rose in the remaining sectors. The same pattern held for payroll shares, except that they fell for wholesaling as well. The changing relative employment weights for these sectors are provided at the bottom of the tables. Manufacturing had the largest percentage fall in its employment weight, while services had the largest increase in its weight. These changing sector weights also contributed to the economy-wide outcomes of Tables 10 and 11.

Finally, there is another point -- somewhat off the track of aggregate concentration measurements, but nevertheless noteworthy -- that relates to the relationship between the employment data and the payroll data for the giants in Table 5. Traditionally, larger firms have paid their employees higher wages than has been the case for smaller firms. The reasons for this have

${ }^{29}$ As a rough numbers equivalent, if there were only two size categories of companies and $91 \%$ of the firms accounted for $9 \%$ of employment while the remaining $9 \%$ of the firms accounted for the remaining $91 \%$ of employment, this would yield a Gini coefficient of 0.82 . A Gini coefficient of 0.84 would be yielded by a similar $92 \%-8 \%$ split between the two categories. 
been an amalgam of greater tendencies to be unionized, to employ employees with higher levels of human capital (partly as a consequence of the greater unionization), and to be more inclined to pay above-market "efficiency" wages, so as to compensate for the decreased monitoring of individual employees that accompanies larger size. These higher relative wages by large companies can be seen in the comparisons of the aggregate concentration percentages in the early years $p$ f the data in

Table 5: The giant firms' share of payroll was larger than their share of employment. ${ }^{30}$

Over time, however, this differential narrowed considerably. Lower levels of and weaker unionization among larger firms was surely part of the explanation for this change. Whether changes in relative levels of human capital and of monitoring costs between the giants and smaller companies also played roles in this change may be a topic for future research.

\section{B. Forbes magazine data}

Though less well known than the Fortune lists, Eorbes magazine has been compiling "500" lists since 1958. The Forbes lists are similar to but somewhat different from their better-known rival's lists. First, from the beginning, Forbes did not restrict itself to "industrial" companies but covered the entire private sector. Second, Forbes has annually compiled four "500" lists -- based on sales revenue, profits, assets, and stock market value. In addition, from 1980 onward, Forbes has reported the aggregate employment of all of the companies that ranked in the top 500 on at least one of its lists. (This total number of companies varies from year to year but is usually in the $770-820$ range.)

The Forbes lists thus have the major advantages of broad coverage and year-to-year consistency in coverage. ${ }^{31}$ But they share with the Eortune lists the disadvantage of presenting

${ }^{30}$ And, of course, smaller firms' shares of employment exceeded their shares of payroll in Table 8.

${ }^{31}$ By contrast, the Fortune lists have not had employment data consistently available for either their largest 500 or their largest 1,000 for any extensive period. 
consolidated company information, which means that the companies' non-U.S. operations are included, and of excluding companies that are not headquartered in the U.S., even if (e.g., DaimlerChrysler) they have substantial U.S. operations.

For our purposes the advantage opt-weigh the disadvantages. The opportunity to use a data set with consistent corefage from $1980^{32}$ through 2000 for the two major components of corporate value added -- profits $^{33}$ and employment -- is too good to pass up. The other three series in the Forbes lists, however, are too flawed for computations of aggregate concentration. The drawbacks to using sales and assets were discussed above in Section III. The use of stock market value would restrict the universe over which aggregate concentration would be calculated to only the (approximately) 10,000 publicly traded companies and thus would miss much of what the social/political concern about aggregate concentration is all about.

In the first two columns of Table 6 we present the Forbes data on after-tax profits for the largest 500 U.S. companies (ranked by profits) in each year and on employment for all of the companies that entered the four Eorbes lists in that year, along with the number of such companies; in the pext two columns we present the relevant national aggregates -- total U.S. after-tax corporate profits $^{34}$ and private sector employment; the final two columns present the relevant ratios. As can

321980 is chosen for the starting date for two reasons. First, it is the first year for which employment data from the Forbes lists are available. Second, it allows us to pick up where White (1981) left off.

${ }^{33}$ The potential drawbacks to using publicly reported company data on profits, discussed above, still remain and seem unavoidable if the profits component of corporate value added is going to enter an aggregate concentration measure.

34 The IRS Statistics of Income, Corporations publications are the source of these data. The IRS data are compiled from corporate tax returns, which should make them reasonably comparable to the company-reported after-tax profits of the Forbes lists. An alternative source of after-tax corporate profits data, the national income accounts, also include inventory valuation and capital consumption adjustments. The IRS data, however, are currently available only through 1998 . To estimate the 1999 and 2000 values, I regressed (OLS) the IRS data against the national income data for the years 1980-1998, and used that equation and the national income figures for 1999 and 2000 
be seen, aggregate concentration as measured by the profits of the largest 500 companies generally trended downward through 1998, and then rose $;^{35}$ but the percentage values for 1999 and 2000 were well below the values of the early 1980s and were in the range of the early-1990s percentages. The employment percentages trended downward through 1995 and then rose ${ }^{36}$ the percentage in 2000 was well below that of the early 1980s and was comparable to those of the late 1980s and early 1990s.

Thus, the aggregate concentration estimates drawn from the Forbes lists are quite consistent with those based on the Census Bureau data: Aggregate concentration has not increased since the late 1980s. The Forbes data also indicate that aggregate concentration has decreased since the early 1980s.

to estimate the IRS figures. That estimating equation is as follows (t-statistics are in parentheses):

$$
\begin{aligned}
& \Pi_{\mathrm{IRS}}=-97.19+1.45 \Pi_{\mathrm{NI}} \\
& \mathrm{R}^{2}=0.93
\end{aligned}
$$

${ }^{35}$ The 1982 ratio of greater than $100 \%$ is due to the IRS data's showing large numbers of companies with losses for that year, so that the aggregate (net) profits for all corporations were below the profits of the largest 500 (who were selected by Eorbes to be those with the largest profits and thus none of whom had losses).

${ }^{36}$ The varying number of companies from which the Forbes employment aggregate is calculated might seem to create an excessive margin for error for the employment calculations. However, the ending-year number of companies (817 companies in 2000) was virtually identical to the beginning-year number of companies (818 companies in 1980), which facilitates beginning and ending comparisons. Further, with the exception of the anomalous 895 companies in 1999, the number of companies for the remaining year all fell within the range of 774-818 companies. Though Forbes does not list the employment levels for each company, Fortune does list company employment for its list covering company rankings for 2000. The 45 companies that spanned Fortune's 774-818 rankings in 2000 (based on sales revenue) had a total employment of 448,000. This 448,000 constituted only $1.8 \%$ of the total employment of 24.9 million for the 817 Forbes companies shown in Table 12 for 2000. Thus, the modestly varying number of companies through the years were unlikely to have affected the clear trends shown in that table. 


\section{Conclusion}

\section{A. A summary of the findings.}

The results of the previous section are clear and strong: Aggregate concentration in the U.S. -- the fraction of private-sector economic activity accounted for by the largest $\mathbf{X}$ companies in the U.S. -- declined during the 1980s, and declined further in the early 1990 s and then increased by the late 1990 s only to the levels of the late 1980s or early 1990s. Overall, aggregate concentration has clearly not risen since the late 1980s and has declined since the early 1980s, despite the substantial merger wave of the 1980s and the far greater merger wave of the 1990s. Tables 5 and 12 offer straightforward evidence of these conclusions.

These economy-wide results for the 1980s and 1990s are consistent with the evidence described and presented in Section III for the long-term value-added data that are narrowly focused on manufacturing (Table 1), for the long-term data describing the assets of non-financial corporations (Table 2), and for economy-wide aggregate concentration trends in the 1970s (Table 3).

Though aggregate concentration has not risen, however, the average size of company has increased, and the fraction of employment and payroll accounted for by companies in the larger size categories has increased. From Tables 7 and 8, in 1988 there were 6,369 companies in the U.S. with 1,000-or-more employees; they constituted $0.013 \%$ of all companies, but they employed $40.4 \%$ of all private-sector workers, and they accounted for $46.6 \%$ of all private-sector payroll. A decade later, in 1998, there were 8,312 companies with 1,000-or-more employees; they now constituted $0.015 \%$ of all companies, and they employed $44.0 \%$ of all private-sector employees and accounted for $49.3 \%$ of all private-sector payroll. As a summary measure of increased skewness and inequality in firm sizes, the Gini coefficients for private-sector employment and payroll increased modestly but steadily from 1988 through 1998 (Table 9). 
Thus, though the giants of the economy have not expanded their shares of economic activity, the relative importance of large companies has increased somewhat. This increase, though should be kept in context. Between 1988 and 1998 the total number of "employer firms" increased by over $10 \%$, and the aggregate numbers of companies and of employment and payroll increased in all size categories. Thus, though small companies were declining somewhat in relative importance (Table 6), they were far from an endangered species.

\section{B. Some hypotheses about these patterns.}

The major goal of this article was to lay out the new data on economy-wide aggregate concentration. The rigorous testing of hypotheses to explain these patterns will have to await future research.

Nevertheless, we can offer some tentative hypotheses that may help guide that future research. We will focus primarily on addressing the question, why hasn't aggregate concentration increased?

One set of possibilities would focus on the advantages and disadvantages of firm size. "Very" large size may be a disadvantage: The "U"-shape average cost curve (rather than an "L" or even a rectangular hyperbola) may be an accurate representation of the relative advantages and disadvantages of size in a horizontal sense; the net advantages of much vertical integration may be

overblown; and economies of scope in most areas may be weak. ${ }^{37}$ CEOs who are empire-minded or just excessively optimistic, and who are poorly restrained by weak corporate governance procedures, may try constantly to create giant firms through M\&As; but economic reality eventually intrudes and forces shrinkage and spinoffs.

${ }^{37}$ Of course, industry specifics, technology specifics, and even organization specifics will be important determinants of what size (in various dimensions) is efficient and what size is excessively large. 
Another set of possibilities focuses on the M\&A data itself, which may be overstating the extent to which the registered transactions automatically imply an increase in corporate size. First, about a third of the transactions that are included in the "M\&A" lists are divestitures: ${ }^{38}$ Company A is spinning off a subsidiary. This subsidiary may be become a stand-alone entity, in which case aggregate concentration automatically decreases; or it may be bought by another company, in which case aggregate concentration can increase or decrease, depending on the size of the acquiring company as compared to the divesting company. Unfortunately, there are no readily available data that would allow further investigation of divestitures.

Second, mpre than a seventh of the M\&A totals involve U.S. companies' purchases of nonU.S. companies. $^{39}$ If the acquired company has no U.S. activities, this transaction would yield no immediate change in aggregate concentration, as measured by the Bureau of the Census data; there could be a subsequent decrease in aggregate concentration as measured by these data if the combined firm achieved company-wide efficiencies and resource re-allocations that led to a decrease in U.S. resources employed. The transaction would increase aggregate concentration as measured by the Forbes lists, however. Only if the acquired (non-U.S.) company had U.S. operations would the acquisition increase aggregate concentration as indicated by both measures.

Third, about a ten of the M\&A totals involve non-U.S. companies' purchases of U.S.headquartered companies. ${ }^{40}$ The immediate consequences for the Forbes list has already been

38 For 1991-2000, the ratio of divestitures to total M\&As listed by Mergers \& Acquisitions magazine was $35.1 \%$; for Mergerstat that percentage was $29.7 \%$.

39 For 1991-2000 the ratio of transactions involving a U.S. company's purchase of a non-U.S. company to total M\&As listed by Mergers \& Acquisitions magazine was 15.5\%; for Mergerstat the ratio was $14.6 \%$. These percentages and the divestiture percentages are not exclusive of each other and contain some overlapping transactions.

${ }^{40}$ For 1991-2000 the ratio of transactions involving a non-U.S. company purchasing a U.S. company to the total M\&As listed by Mergers \& Acquisitions magazine was $10.4 \%$; for Mergerstat the ratio was $8.6 \%$. Again, these percentages and the divestiture percentages are not exclusive of each other. 
noted: The acquired company disappears from the list, and the acquiring company does not replace it; aggregate concentration automatically decreases. The effect on the Census Bureau measure is, again, more nuanced: If the acquiring (non-U.S.) company did not have previous U.S. activities, aggregate concentration is not immediately affected; if the combined company effects sufficient company-wide efficiencies and resource re-allocations so that resources employed by the acquired unit in the U.S. decrease, aggregate concentration will subsequently decrease; and if the acquiring company already had operations in the U.S., then aggregate concentration increases (although subsequent rationalization of the combined U.S. operations may yield an offset).

Finally, as was discussed in Section IV, neither the Forbes data nor the Bureau of the Census data are perfect, and they may yield misleading calculations of aggregate concentration. The Forbes data have all of the imperfections of relying on consolidated company data, so that nonU.S. operations are included, even in the absence of the complications just discussed of the M\&As that involved non-U.S. companies during the years covered. Also, the Forbes after-tax profit data are subject to the vagaries of accounting and tax variations. The Bureau of the Census data encompass only employment and payroll and cover only a relatively short period; they do not encompass corporate profits, the other important component of value added, and thus cannot provide be a more comprehensive measure of aggregate concentration. Still, this last hypothesis -- that the data are misrepresenting the true trends in aggregate concentration -- seems the weakest possibility, since there are no apparent biases in these data that would be pushing them to understate aggregate concentration.

The other noticeable pattern -- the rising relative importance of firms in the larger size categories (though not the giants) -- may be due to a number of influences. First, in some industries the importance of sunk costs, such as advertising and promotion, may be growing, and, as a consequence, the relative advantages of larger firms may be growing as well; also, as Kwoka and White (2001) argue (following Sutton (1991)), the rising importance of sunk costs may be 
endogenous -- the result of the decisions of the leading firms in those industries.

Second, the rising importance of exports for the U.S. economy has likely had a positive influence on firm size, since the development and maintenance of overseas markets involve sunk costs and thus scale.

Third, improved technologies of managing and monitoring may have helped overcome the inherent difficulties of managing larger organizations (Williamson 1967) and thus encouraged larger enterprises.

Finally, the changing weights of the major sectors of the economy -- especially the expanding importance of services and the shrinking relative importance of manufacturing (Tables 10 and 11) -- also played a role, since the relative importance of large firms in manufacturing was shrinking while the relative importance of large firms in services was growing.

Overall, the findings of this study, as well of previous studies, that aggregate concentration in the U.S. economy has not been increasing, despite recent merger waves, may appear as somewhat of a surprise. But there are potential plausible hypotheses to explain these results. Further research, while refining these aggregate concentration measures, may also be able to shed further light on the possible explanations for their pattern. 


\section{Appendix}

The M\&A series published by Mergerstat pertain to "announcements". The series for the annual-number of mergers begins in 1963; the series for the annual value of mergers begins in 1968. ${ }^{41}$ Mergerstat describes its minimum transaction size criteria (for inclusion in their series, as of 2001) as follows: "Mergerstat tracks formal transfers of ownership of at least $10 \%$ of a company's equity where the purchase price is at least $\$ 1,000,000$ and where at least one of the parties is a U.S. entity." These criteria were adopted in 1989. Prior to that year the minimum purchase price was $\$ 500,000$. Unfortunately, Mergerstat made no adjustment to its historical data when the new criteria were adopted, so the pre-1988 data are (for our purposes) upward biased.

The M\&A series published by Mergers \& Acquisitions pertain to "completions". The series for the annual nmber of M\&As begins in 1967, and the series for the annual value of M\&As begins in 1979. ${ }^{42}$ Mergers \& Acquisitions describes its minimum transaction size criteria (for inclusion in the series, as of 2001) as "all completed mergers, acquisition, and divestitures priced at $\$ 5$ million and over, as well as purchases of partial interest that involve at least a $40 \%$ stake in the target company or an investment of at least \$100." Also, the transactions must have an American company on at least one side of the transaction. These criteria were adopted in 1991; prior to that year, from the fourth quarter of 1980 through 1990 the criteria were "a transaction must involve a U.S. company and must be valued at $\$ 1$ million or more. Partial acquisitions of $\% 5$ or more of a company's capital stock are included if the payments are $\$ 1$ million or more." And before the fourth quarter of 1980 the minimum criterion was $\$ 700,000$.

The 1991 criteria were applied by M\&A to its historical data back to 1982; unfortunately,

\footnotetext{
${ }^{41}$ Prior to 1988 this series was published by W.T. Grimm \& Co.

42 This is the same series that has been compiled and released by the Securities Data Co., now Thomson Financial Securities Data Co.
} 
no historical data adjustments were made at the time of the 1980 change. In order to adjust M\&A's number of mergers for 1981 and earlier years to the 1991-and-after criteria, I used the ratio of M\&A's post-adjustment number of mergers for 1982 to M\&A's pre-adjustment number of mergers for 1982 as a multiplicand. A similar procedure was used to adjust M\&A's value of mergers for 1979-1981.

Since both sources use a fixed minimum purchase price criterion, their series will tend to show an upward bias over time in an inflationary era. 


\section{References}

Armington, Catherine, "Statistics of U.S. Businesses -- Microdata and Tables," Office of Advocacy, Small Business Administration (1998).

Berle, Adolf A. and Gardiner C. Means, The Modern Corporation and Private Property. New York: Macmillan, 1932.

Bernheim, B. Douglas and Michael D. Whinston, "Multimarket Contact and Collusive Behavior," Rand Journal of Economics, 21 (Spring 1990), pp. 1-25.

Black, Bernard S., "The First International Merger Wave (and the Fifth and Last U.S. Wave)," University of MiamiLaw Review, 54 (2000), pp. 799-818.

Feinberg, Robert, "Sales-at-Risk: A Test of Mutual Forbearance Theory of Conglomerate Behavior," Journal of Business, 58 (April 1985), pp. 225-241.

Ginsberg, Douglas H., "Statement," Subcommittee on Monopolies and Commercial Law, Committee on the Judiciary, U.S. House of Representatives, March 5, 1986.

Golbe, Devra L. and Lawrence J. White, "A Time Series Analysis of Mergers and Acquisitions in the U.S. Economy," in Alan J. Auerbach, ed., Corporate Takeovers: Causes and Consequences. Chicago: University of Chicago Press, 1988, pp. 265-302.

Golbe, Devra G. and Lawrence J. White, "Catch a Wave: The Time Series Behavior of Mergers," Review of Economics and Statistics, 75 (August 1993), pp. 493-499.

Kwoka, John E., Jr., and Lawrence J. White, "The New Industrial Organization and Small Business," Small Business Economics, 16 (February 2001), pp. 21-30.

Pryor, Frederick L., "Dimensions of the Worldwide Merger Wave," Journal of Economic Issues, forthcoming (a).

Pryor, Frederick L., "Will Most of Us Be Working for Giant Enterprises by 2028?" Journal of Economic Behavior and Organization, forthcoming (b).

Rhoades, Stephen A. and Arnold Heggestad, "Multimarket Interdependence and Performance in Banking: Two Tests," Antitrust Bulletin, 30 (1985), pp. 975-995.

Robb, Alicia, "New Data for Dynamic Analysis: Research Using Confidential Microdata at the Center of Economic Studies, U.S. Census Bureau," Office of Advocacy, Small Business Administration (1999). 
Robb, Alicia, "New Data for Dynamic Analysis: The Business Information Tracking System (BITS)." Washington, D.C.: U.S. Small Business Administration, Office of Advocacy (January 2000).

Scherer, F.M., Industrial Market Structure and Economic Performance. Chicago: Rand McNally, 1970.

Scherer, F.M., Industrial Market Structure and Economic Performance, 2nd edn. Chicago: Rand McNally, 1980.

Scherer, F.M. and David Ross, Industrial Market Structure and Economic Performance, 3rd edn. Boston: Houghton-Mifflin, 1990.

Sutton, John, Sunk Costs and Market Structure: Price Competition, Advertising, and the Evolution of Concentration. Cambridge, Mass.: MIT Press, 1991.

White, Lawrence J., "What Has Been Happening to Aggregate Concentration in the United States?" Journal of Industrial Economics, 29 (March 1981), pp. 223-230.

White, Lawrence J., "The Community Reinvestment Act: Good Intentions Headed in the Wrong Direction," Fordham Urban Law Journal, 20 (Winter 1993), pp. 281-292.

White, Lawrence J., "Tying, Banking, and Antitrust: It's Time for a Change," Contemporary Policy Issues, 13 (October 1995), pp. 26-35.

Williamson, Oliver E., "Hierarchical Control and Optimum Firm Size," Journal of Political Economy, 75 (February 1967), pp. 123-138.

Yellen, Janet L., "Testimony," Committee on the Judiciary, U.S. Senate, June 16, 1998. 


\section{Figure 1: Annual Number of Large Mergers, 1963-2000}

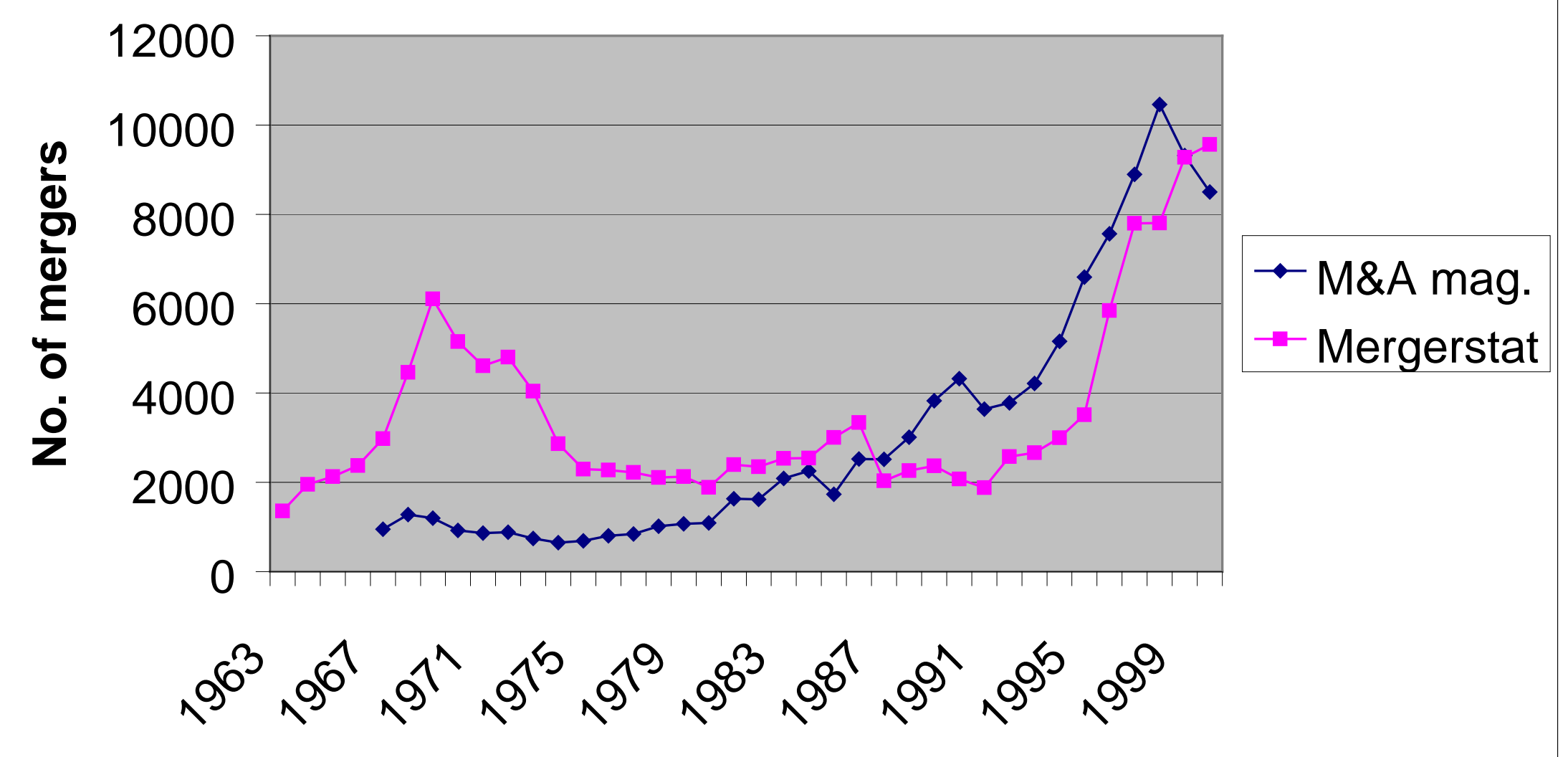


Figure 2: Annual Value of Large Mergers, 1968 . 2000 (\$billions)

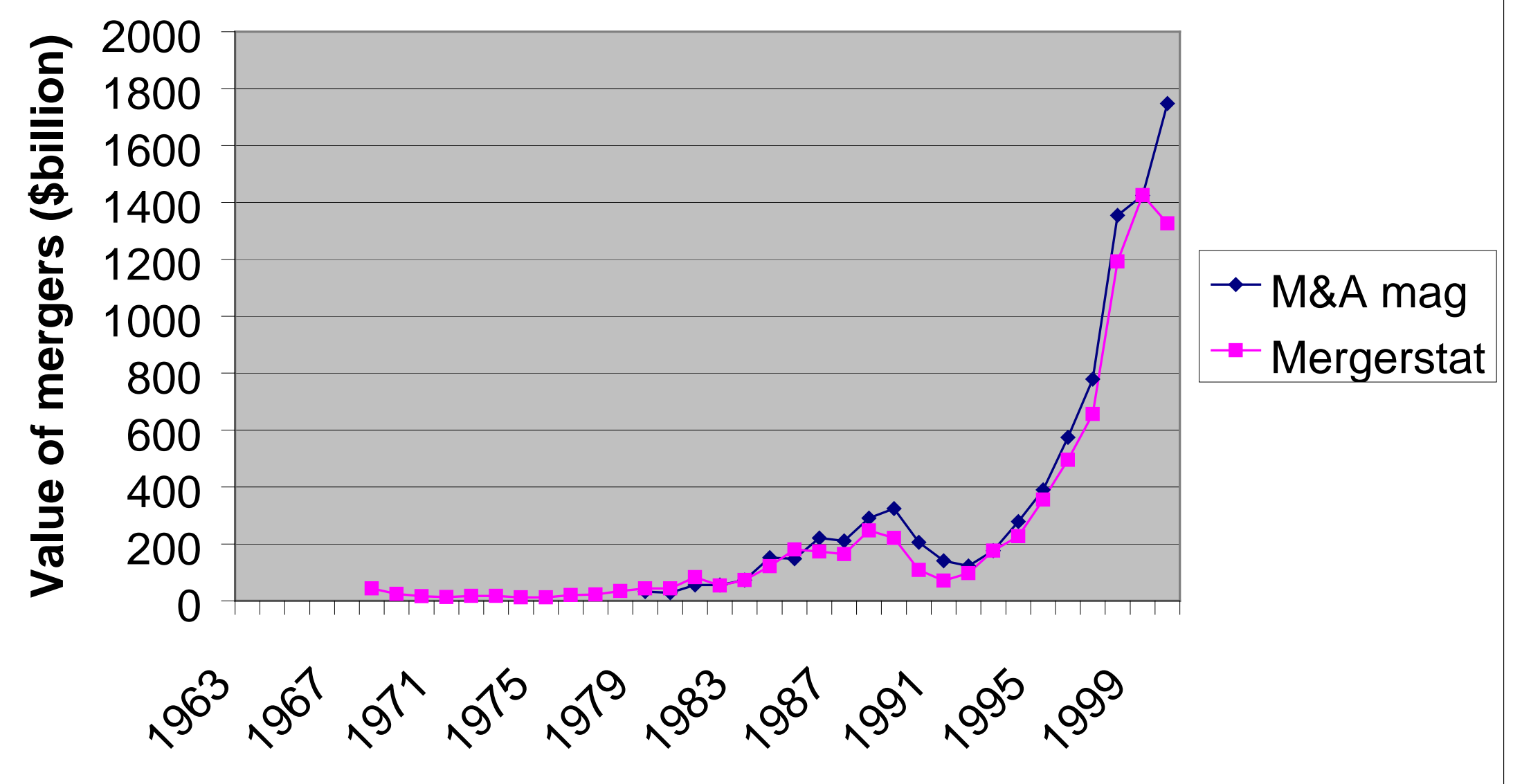


Figure 3: Annual Number of Large Mergers Divided by Real GDP, 1963-2000 (Index numbers: $1980=100$ )

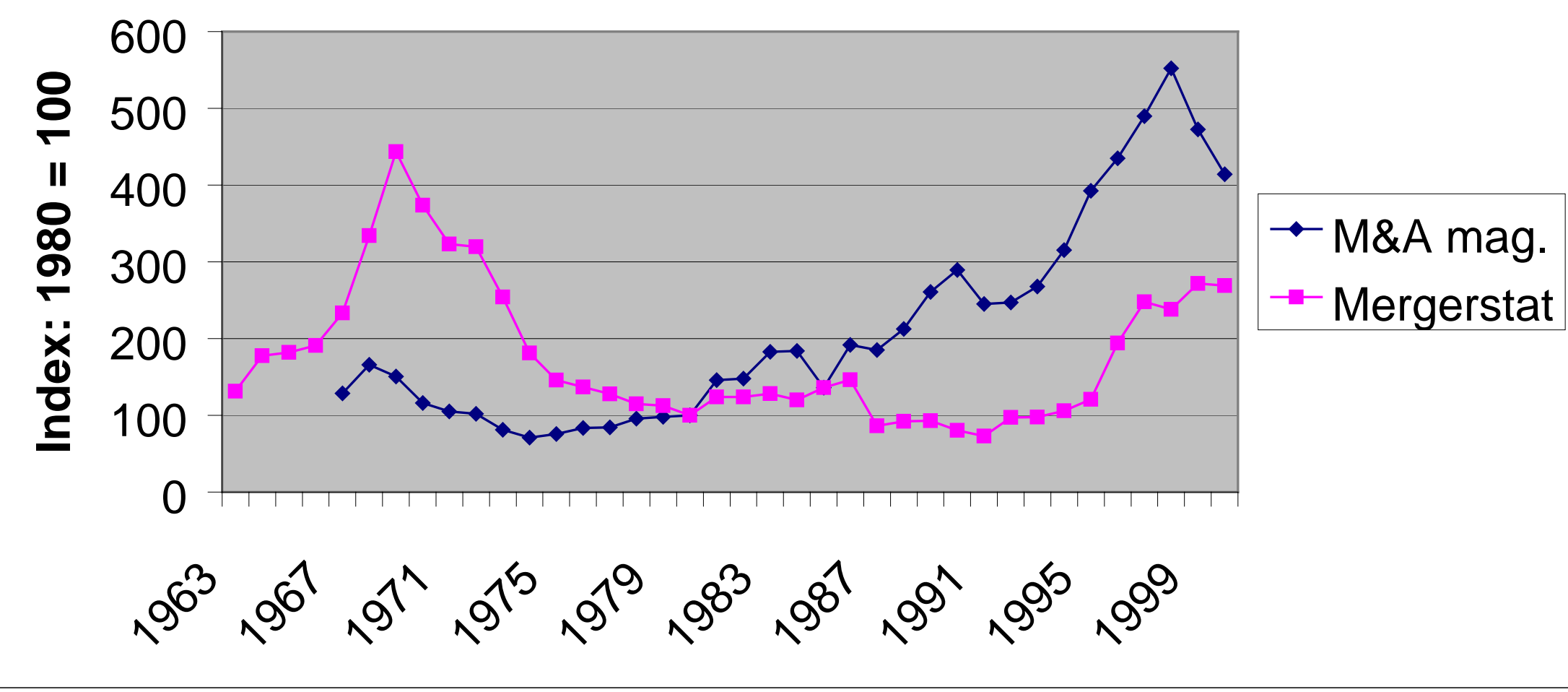


Figure 4: Annual Number of Large Mergers Divided by Number of Corporations, 1963-2000 (Index numbers: $1980=100$ )

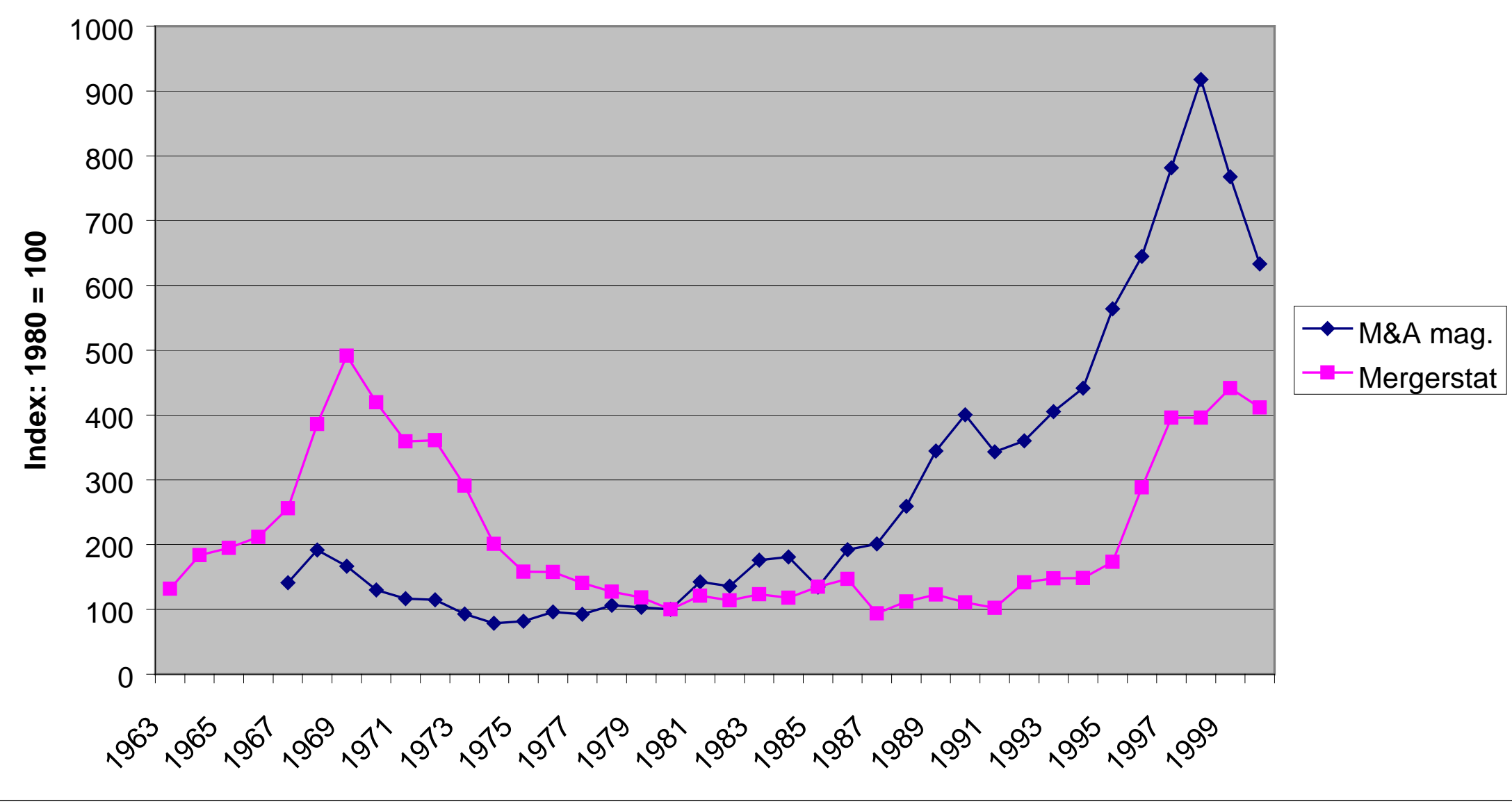




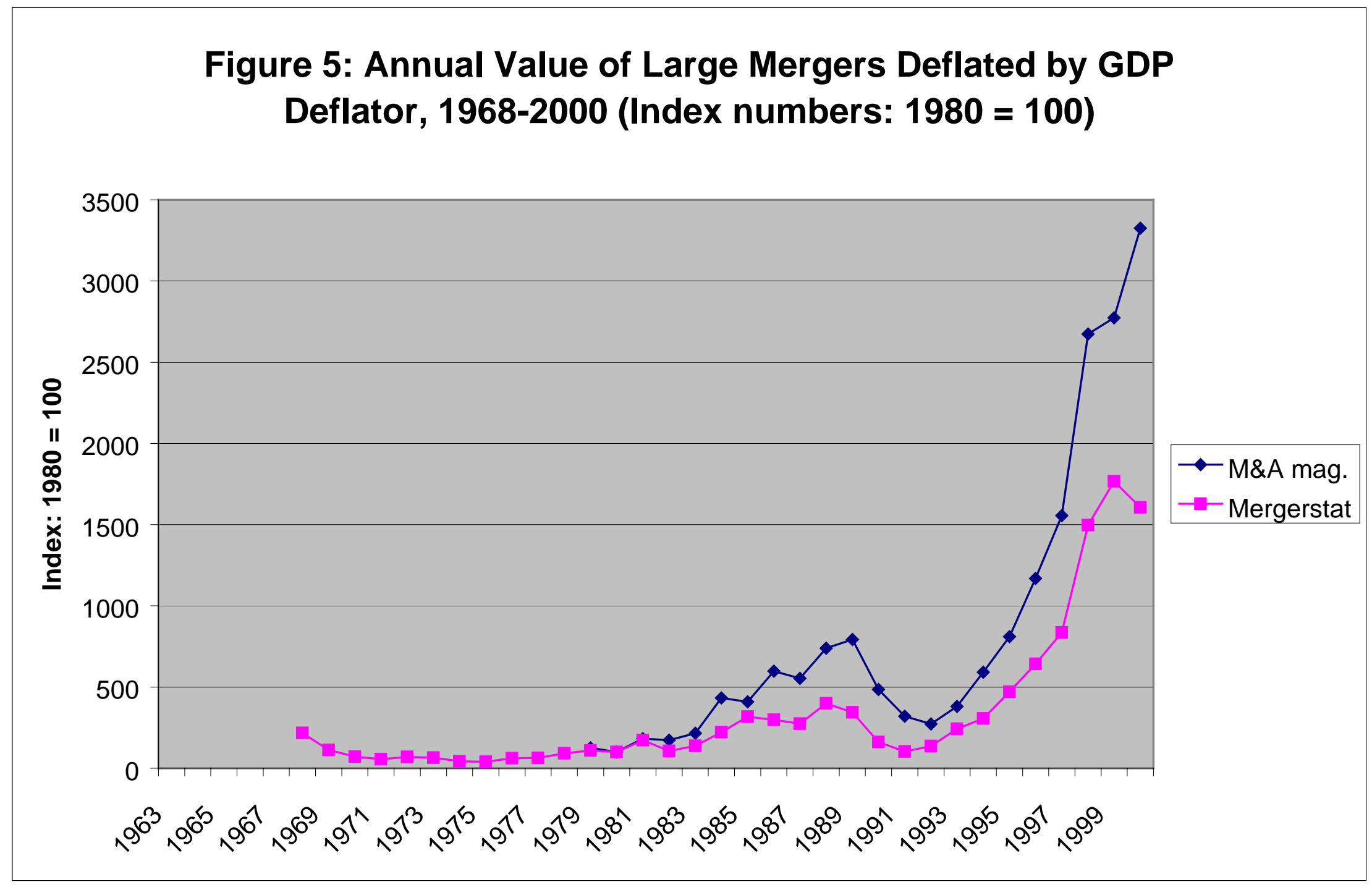


Figure 6: Annual Value of Large Mergers Divided by Nominal GDP, 1968-2000 (Index numbers: $1980=100$ )

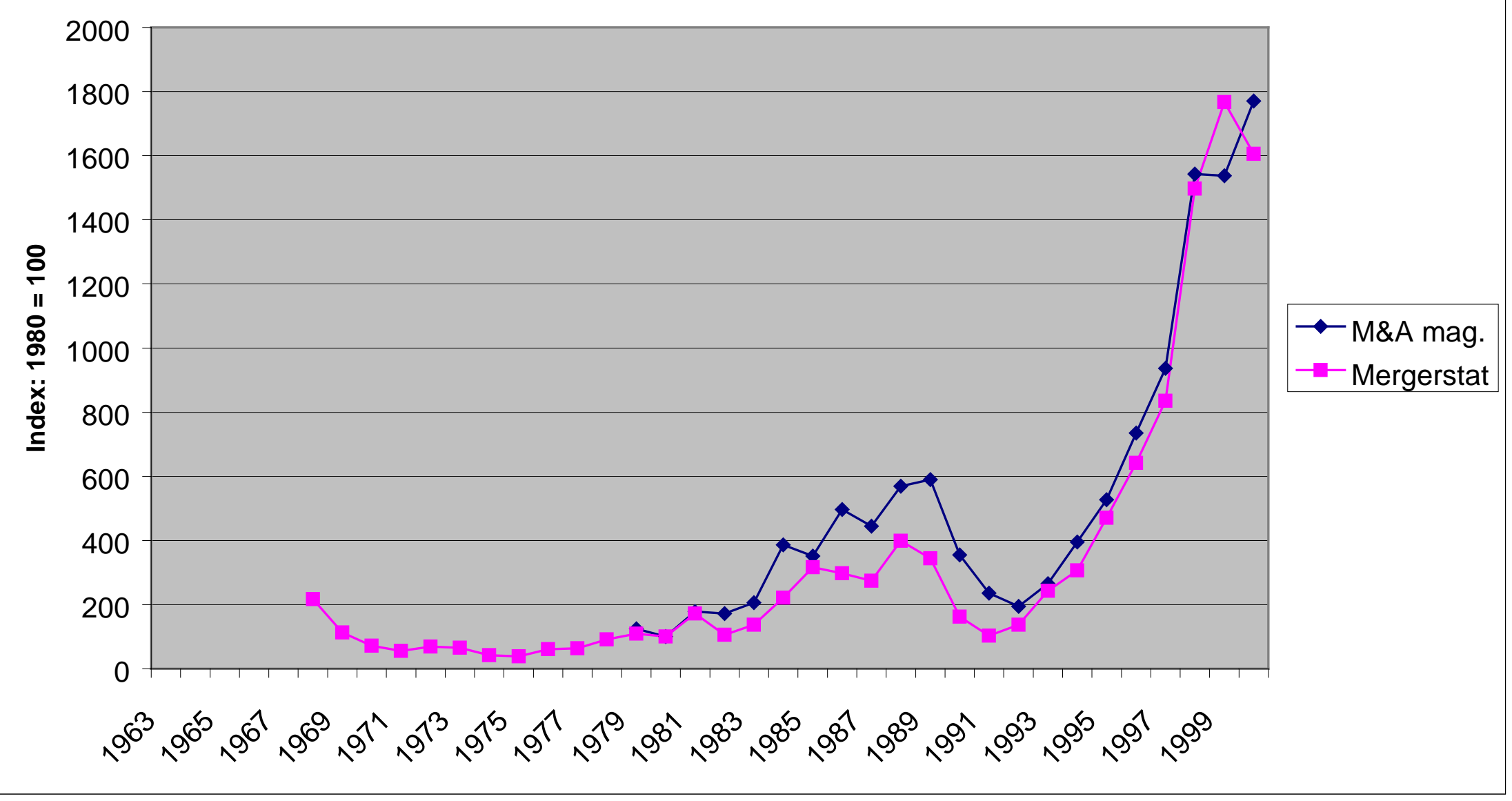


Figure 7: Annual Value of Large Mergers Divided by Aggregate Stock Market Value, 1968-2000 (Index numbers: $1980=100$ )

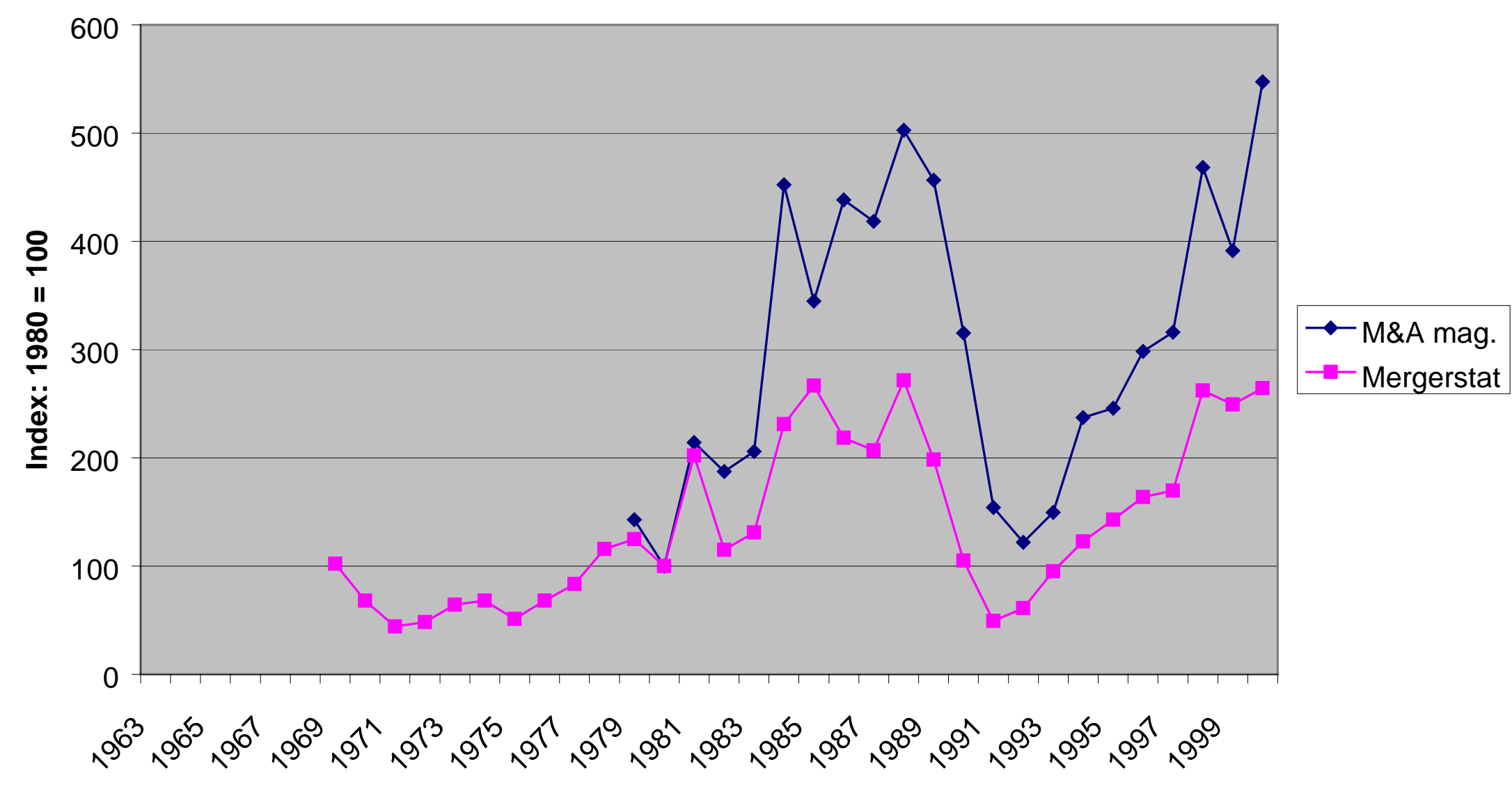


Table 1: Aggregate Concentration in Manufacturing, as Measured by Value Added, 1947-1997

\begin{tabular}{|l|l|l|l|l|}
\hline & \multicolumn{5}{|c|}{ Share of Total Value Added in Manufacturing Sector } \\
\hline Year & Largest 50 Cos. & Largest 100 Cos. & Largest 150 Cos. & Largest 200 Cos. \\
\hline 1947 & $17 \%$ & $23 \%$ & $27 \%$ & $30 \%$ \\
\hline 1954 & 23 & 30 & 34 & 37 \\
\hline 1958 & 23 & 30 & 35 & 38 \\
\hline $1962^{*}$ & 24 & 32 & 36 & 35 \\
\hline 1963 & 25 & 33 & 37 & 41 \\
\hline $1966^{*}$ & 25 & 33 & 38 & 42 \\
\hline 1967 & 25 & 33 & 38 & 42 \\
\hline $1970 *$ & 24 & 33 & 38 & 43 \\
\hline 1972 & 25 & 33 & 39 & 43 \\
\hline $1976 *$ & 24 & 33 & 39 & 44 \\
\hline 1977 & 24 & 33 & 39 & 44 \\
\hline 1982 & 25 & 33 & 39 & 43 \\
\hline 1987 & 25 & 33 & 39 & 43 \\
\hline 1992 & 24 & 32 & 38 & 42 \\
\hline 1997 & 24 & 32 & & 40 \\
\hline
\end{tabular}

Note: Data are for economic census years, except for years with a $\left(^{*}\right)$, which draw on the Census Bureau's Annual Survey of Manufactures.

Source: U.S. Bureau of the Census, Census of Manufactures, various years; Survey of Manufactures, various years. 
Table 2: Aggregate Concentration in the Non-Financial Private Sector, as Measured by Assets, 1958-1988

\begin{tabular}{|l|l|l|l|l|}
\hline & \multicolumn{4}{|c|}{ Share of Total Assets of Non-Financial Private Sector } \\
\hline Year & Largest 50 Cos. & Largest 100 Cos. & Largest 150 Cos. & Largest 200 Cos. \\
\hline 1958 & $23.9 \%$ & $31.6 \%$ & $36.5 \%$ & $40.0 \%$ \\
\hline 1963 & 24.2 & 31.3 & 36.3 & 39.9 \\
\hline 1967 & 24.5 & 31.9 & 37.1 & 41.0 \\
\hline 1972 & 23.2 & 30.5 & 35.7 & 39.7 \\
\hline 1974 & 23.2 & 30.4 & 35.5 & 39.2 \\
\hline 1975 & 23.3 & 30.6 & 35.6 & 39.5 \\
\hline 1976 & 23.3 & 30.4 & 35.3 & 39.1 \\
\hline 1977 & 22.7 & 29.7 & 34.5 & 38.3 \\
\hline 1978 & 22.3 & 29.2 & 34.0 & 37.7 \\
\hline 1979 & 21.9 & 28.9 & 33.7 & 37.4 \\
\hline 1980 & 22.4 & 29.4 & 34.0 & 37.7 \\
\hline 1981 & 22.2 & 28.8 & 33.3 & 36.9 \\
\hline 1982 & 21.4 & 27.7 & 32.1 & 35.4 \\
\hline 1983 & 21.0 & 27.3 & 31.6 & 34.9 \\
\hline 1984 & 19.7 & 26.4 & 30.7 & 33.9 \\
\hline 1985 & 19.3 & 25.8 & 29.1 & 32.8 \\
\hline 1986 & 18.6 & 25.1 & 29.9 & 32.2 \\
\hline 1987 & 18.6 & 25.1 & 29.1 & 32.1 \\
\hline 1988 & 18.7 & 25.1 & 29.2 & 32.2 \\
\hline & & & & \\
\hline
\end{tabular}

Source: Yellen (1998). 
Table 3: Aggregate Concentration in the Entire Private Sector, as Measured by Employment and by Profits, 1972-1980

\begin{tabular}{|l|l|l|l|l|l|l|}
\hline & \multicolumn{2}{|c|}{$\begin{array}{r}\text { Share of Total Non-Farm Private } \\
\text { Sector Employment }\end{array}$} & \multicolumn{2}{c|}{$\begin{array}{r}\text { Share of Total Corporate Profits after } \\
\text { Taxes }\end{array}$} \\
\hline & $\begin{array}{l}\text { Largest } \\
\text { Year }\end{array}$ & $\begin{array}{l}\text { Largest } \\
100 \text { Cos. }\end{array}$ & $\begin{array}{l}\text { Largest } \\
200 \text { Cos. }\end{array}$ & $\begin{array}{l}\text { Largest } \\
1,300 \text { Cos. }\end{array}$ & $\begin{array}{l}\text { Largest } \\
100 \text { Cos. }\end{array}$ & $\begin{array}{l}\text { Largest } \\
200 \text { Cos. }\end{array}$ \\
1972 & $18.2 \%$ & $23.9 \%$ & $37.3 \%$ & $43.3 \%$ & $55.4 \%$ & $76.6 \%$ \\
\hline 1973 & n.a & n.a. & 37.4 & n.a. & n.a. & 75.1 \\
\hline 1974 & n.a. & n.a. & 37.0 & n.a. & n.a. & 72.6 \\
\hline 1975 & n.a. & n.a. & 36.5 & n.a. & n.a. & 71.4 \\
\hline 1976 & n.a. & n.a. & 36.1 & n.a. & n.a. & 73.8 \\
\hline 1977 & 17.3 & 22.7 & 35.5 & 39.8 & 50.2 & 71.4 \\
\hline 1978 & n.a. & n.a. & 34.7 & n.a. & n.a. & 70.4 \\
\hline 1979 & 16.7 & 22.6 & 34.2 & 39.4 & 49.9 & 71.1 \\
\hline 1980 & 16.6 & 22.1 & 34.0 & 44.9 & 56.5 & 75.6 \\
\hline
\end{tabular}

Sources: White (1981); Golbe and White (1986). 
Table 4: Economy-Wide Numbers, Employment, and Payrolls of Companies, 19881998

\begin{tabular}{|l|l|l|l|l|l|}
\hline & $\begin{array}{l}\text { Aggregate } \\
\text { Number of } \\
\text { Companies } \\
\text { (thousand) }\end{array}$ & $\begin{array}{l}\text { Aggregate } \\
\text { Employment } \\
\text { (thousand) }\end{array}$ & $\begin{array}{l}\text { Aggregate } \\
\text { Payroll } \\
\text { (billion) }\end{array}$ & $\begin{array}{l}\text { Average } \\
\text { Employment } \\
\text { Per Company }\end{array}$ & $\begin{array}{l}\text { Average } \\
\text { Payroll } \\
\text { Per Company } \\
\text { (thousand) }\end{array}$ \\
\hline 1988 & 4,955 & 87,844 & $\$ 1,859$ & 17.7 & $\$ 375.2$ \\
\hline 1989 & 5,021 & 91,626 & 1,990 & 18.2 & 396.3 \\
\hline 1990 & 5,073 & 93,469 & 2,104 & 18.4 & 414.7 \\
\hline 1991 & 5,051 & 92,308 & 2,145 & 18.3 & 424.7 \\
\hline 1992 & 5,095 & 92,828 & 2,272 & 18.2 & 445.9 \\
\hline 1993 & 5,194 & 94,774 & 2,363 & 18.2 & 454.9 \\
\hline 1994 & 5,277 & 96,722 & 2,488 & 18.3 & 471.5 \\
\hline 1995 & 5,369 & 100,315 & 2,666 & 18.7 & 496.6 \\
\hline 1996 & 5,478 & 102,187 & 2,849 & 18.7 & 520.1 \\
\hline 1997 & 5,542 & 105,299 & 3,048 & 19.0 & 550.0 \\
\hline 1998 & 5,579 & 108,118 & 3,309 & 19.4 & 593.1 \\
\hline
\end{tabular}

Source: U.S. Bureau of the Census, "Statistics of U.S. Busines" 
Table 5: Aggregate Concentration in the Entire Private Sector, as Measured by Employment and Payroll, 1988-1998

\begin{tabular}{|l|l|l|l|}
\hline & Largest & Largest & Largest \\
Year & 100 Cos. & 500 Cos. & 1,000 Cos. \\
\hline
\end{tabular}

Panel A: Share of Total Private-Sector Employment

\begin{tabular}{|l|l|l|l|}
\hline 1988 & $11.3 \%$ & $21.9 \%$ & $27.1 \%$ \\
\hline 1989 & 11.1 & 21.5 & 26.6 \\
\hline 1990 & 11.0 & 21.4 & 26.6 \\
\hline 1991 & 11.1 & 21.6 & 26.8 \\
\hline 1992 & 10.9 & 21.3 & 26.6 \\
\hline 1993 & 10.7 & 20.8 & 26.1 \\
\hline 1994 & 10.6 & 20.7 & 26.1 \\
\hline 1995 & 10.5 & 20.7 & 26.1 \\
\hline 1996 & 10.6 & 20.9 & 26.5 \\
\hline 1997 & 10.9 & 21.2 & 26.7 \\
\hline & 10.8 & 21.5 & 27.1 \\
\hline
\end{tabular}

Panel B: Share of Total Private-Sector Payroll

\begin{tabular}{|l|l|l|l|}
\hline 1988 & $13.8 \%$ & $26.3 \%$ & $32.4 \%$ \\
\hline 1989 & 13.6 & 25.6 & 31.2 \\
\hline 1990 & 13.2 & 25.3 & 31.5 \\
\hline 1991 & 13.2 & 25.4 & 31.6 \\
\hline 1992 & 12.9 & 24.9 & 31.3 \\
\hline 1993 & 12.0 & 24.1 & 30.5 \\
\hline 1994 & 11.8 & 23.6 & 29.9 \\
\hline 1995 & 11.7 & 23.6 & 29.8 \\
\hline 1996 & 11.2 & 23.3 & 30.0 \\
\hline 1997 & 11.4 & 23.4 & 30.0 \\
\hline
\end{tabular}

Source: Special tabulation by the Bureau of the Census 
Table 6: Share of Private-Sector Employment and Payroll Accounted for by Small Firms, 1988-1998

\begin{tabular}{|l|l|l|l|l|}
\cline { 2 - 5 } \multicolumn{1}{c|}{} & \multicolumn{2}{c|}{$\begin{array}{c}\text { Share of Total Private-Sector } \\
\text { Employment }\end{array}$} & \multicolumn{2}{c|}{$\begin{array}{c}\text { Share of Total Private-Sector } \\
\text { Payroll }\end{array}$} \\
\hline & $\begin{array}{l}\text { Firms with } \\
\text { Fewer than 100 } \\
\text { Employees }\end{array}$ & $\begin{array}{l}\text { Firms with } \\
\text { Fewer than 500 } \\
\text { Employees }\end{array}$ & $\begin{array}{l}\text { Firms with } \\
\text { Fewer than 100 } \\
\text { Employees }\end{array}$ & $\begin{array}{l}\text { Firms with } \\
\text { Fewer than 500 } \\
\text { Employees }\end{array}$ \\
\hline 1988 & $40.0 \%$ & $54.5 \%$ & $35.4 \%$ & $48.6 \%$ \\
\hline 1989 & 39.3 & 53.9 & 34.7 & 47.9 \\
\hline 1990 & 39.2 & 53.7 & 34.6 & 47.9 \\
\hline 1991 & 38.9 & 53.1 & 34.2 & 47.2 \\
\hline 1992 & 38.7 & 53.0 & 33.8 & 47.0 \\
\hline 1993 & 38.5 & 53.1 & 33.9 & 47.2 \\
\hline 1994 & 38.1 & 52.7 & 33.8 & 47.3 \\
\hline 1995 & 37.9 & 52.5 & 33.4 & 47.0 \\
\hline 1996 & 37.7 & 52.0 & 33.2 & 46.7 \\
\hline 1997 & 37.3 & 51.8 & 32.7 & 46.5 \\
\hline 1998 & 36.7 & 50.9 & 32.2 & 45.7 \\
\hline
\end{tabular}

Source: Kwoka and White (2001); Bureau of the Census 
Table 7: Numbers and Percentage Distribution of Companies, by Employment Size, 1988-1998

\begin{tabular}{|c|c|c|c|c|c|c|c|c|c|c|c|c|}
\hline Year & Total & 1-4 Empl. & 5-9 Empl. & $\begin{array}{l}\text { 10-19 } \\
\text { Empl. }\end{array}$ & $\begin{array}{l}20-99 \\
\text { Empl. }\end{array}$ & $\begin{array}{l}\text { 100-499 } \\
\text { Empl. }\end{array}$ & $\begin{array}{l}500-999 \\
\text { Empl. }\end{array}$ & $\begin{array}{l}1,000- \\
1,499 \\
\text { Empl. }\end{array}$ & $\begin{array}{l}1,500- \\
2,499 \\
\text { Empl. }\end{array}$ & $\begin{array}{l}2,500- \\
4,999 \\
\text { Empl. }\end{array}$ & $\begin{array}{l}\text { 5,000- } \\
9,999 \\
\text { Empl. }\end{array}$ & $\begin{array}{l}10,000+ \\
\text { Empl. }\end{array}$ \\
\hline \multicolumn{13}{|c|}{ Panel A: Number of Companies } \\
\hline 1988 & $4,954,645$ & $2,979,905$ & 923,580 & 540,988 & 430,640 & 66,708 & 6455 & 2142 & 1737 & 1216 & 631 & 643 \\
\hline 1989 & $5,021,315$ & $3,003,224$ & 937,202 & 553,449 & 443,959 & 69,608 & 6926 & 2361 & 1913 & 1331 & 678 & 664 \\
\hline 1990 & $5,073,795$ & $3,020,935$ & 952,030 & 562,610 & 453,732 & 70,465 & 6948 & 2365 & 1965 & 1336 & 703 & 706 \\
\hline 1991 & $5,051,025$ & $3,036,304$ & 941,296 & 551,299 & 439,811 & 68,338 & 6842 & 2379 & 1983 & 1365 & 709 & 699 \\
\hline 1992 & $5,095,356$ & $3,075,280$ & 945,802 & 551,912 & 439,084 & 69,156 & 6892 & 2383 & 1986 & 1434 & 723 & 704 \\
\hline 1993 & $5,193,642$ & $3,139,518$ & 962,481 & 559,602 & 445,900 & 71,512 & 7185 & 2437 & 2080 & 1478 & 726 & 723 \\
\hline 1994 & $5,276,964$ & $3,208,235$ & 964,985 & 563,097 & 452,383 & 73,267 & 7415 & 2451 & 2089 & 1553 & 726 & 763 \\
\hline 1995 & $5,369,068$ & $3,249,573$ & 981,094 & 576,866 & 469,869 & 76,222 & 7566 & 2592 & 2110 & 1632 & 768 & 776 \\
\hline 1996 & $5,478,047$ & $3,327,783$ & 996,356 & 585,844 & 476,312 & 76,136 & 7670 & 2632 & 2117 & 1580 & 796 & 821 \\
\hline 1997 & $5,541,918$ & $3,358,048$ & $1,006,897$ & 593,696 & 487,491 & 79,707 & 7972 & 2659 & 2132 & 1673 & 818 & 825 \\
\hline 1998 & $5,579,177$ & $3,376,351$ & $1,011,849$ & 600,167 & 494,357 & 80,075 & 8055 & 2714 & 2200 & 1654 & 869 & 886 \\
\hline
\end{tabular}

Panel B: Percentage Distribution of Companies

\begin{tabular}{|l|l|l|l|l|l|l|l|l|l|l|l|l|}
\hline 1988 & $100.0 \%$ & $60.14 \%$ & $18.64 \%$ & $10.92 \%$ & $8.69 \%$ & $1.35 \%$ & $0.130 \%$ & $0.043 \%$ & $0.035 \%$ & $0.025 \%$ & $0.013 \%$ & $0.013 \%$ \\
\hline 1989 & 100.0 & 59.81 & 18.66 & 11.02 & 8.84 & 1.39 & 0.138 & 0.047 & 0.038 & 0.027 & 0.014 & 0.013 \\
\hline 1990 & 100.0 & 59.54 & 18.76 & 11.09 & 8.94 & 1.39 & 0.137 & 0.047 & 0.039 & 0.026 & 0.014 & 0.014 \\
\hline 1991 & 100.0 & 60.11 & 18.64 & 10.91 & 8.71 & 1.35 & 0.135 & 0.047 & 0.039 & 0.027 & 0.014 & 0.014 \\
\hline 1992 & 100.0 & 60.35 & 18.56 & 10.83 & 8.62 & 1.36 & 0.135 & 0.047 & 0.039 & 0.028 & 0.014 & 0.014 \\
\hline 1993 & 100.0 & 60.45 & 18.53 & 10.77 & 8.59 & 1.38 & 0.138 & 0.047 & 0.040 & 0.028 & 0.014 & 0.014 \\
\hline 1994 & 100.0 & 60.80 & 18.29 & 10.67 & 8.57 & 1.39 & 0.141 & 0.046 & 0.040 & 0.029 & 0.014 & 0.014 \\
\hline 1995 & 100.0 & 60.52 & 18.27 & 10.74 & 8.75 & 1.42 & 0.141 & 0.048 & 0.039 & 0.030 & 0.014 & 0.014 \\
\hline 1996 & 100.0 & 60.75 & 18.19 & 10.69 & 8.69 & 1.39 & 0.140 & 0.048 & 0.039 & 0.029 & 0.015 & 0.015 \\
\hline 1997 & 100.0 & 60.59 & 18.17 & 10.71 & 8.80 & 1.44 & 0.144 & 0.048 & 0.038 & 0.030 & 0.015 & 0.015 \\
\hline 1998 & 100.0 & 60.52 & 18.14 & 10.76 & 8.86 & 1.44 & 0.144 & 0.049 & 0.039 & 0.030 & 0.016 & 0.016 \\
\hline
\end{tabular}

Source: Special tabulation by the Bureau of the Census 
Table 8: Percentage Distribution of Private-Sector Employment and Payroll, by Employment Size of Company, 1988-1998

\begin{tabular}{|c|c|c|c|c|c|c|c|c|c|c|c|}
\hline Tea & Total & $\begin{array}{l}1-4 \\
\text { Empl. }\end{array}$ & $\begin{array}{l}5-9 \\
\text { Empl. }\end{array}$ & $\begin{array}{l}10-19 \\
\text { Empl. }\end{array}$ & & \begin{tabular}{|l}
$100-$ \\
499 \\
Empl.
\end{tabular} & $\begin{array}{l}500- \\
999 \\
\text { Empl. }\end{array}$ & $\begin{array}{l}1,000- \\
1,499 \\
\text { Empl. }\end{array}$ & $\begin{array}{l}1,500- \\
2,499 \\
\text { Empl. }\end{array}$ & $\begin{array}{l}2,500- \\
4,999 \\
\text { Empl. }\end{array}$ & $\begin{array}{l}5,000- \\
9,999 \\
\text { Empl. }\end{array}$ \\
\hline
\end{tabular}

Panel A: Percentage Distribution of Employment

\begin{tabular}{|l|l|l|l|l|l|l|l|l|l|l|l|l|}
\hline 1988 & $100.0 \%$ & $5.70 \%$ & $6.90 \%$ & $8.26 \%$ & $19.16 \%$ & $14.53 \%$ & $5.07 \%$ & $2.97 \%$ & $3.78 \%$ & $4.80 \%$ & $5.03 \%$ & $23.81 \%$ \\
\hline 1989 & 100.0 & 5.52 & 6.71 & 8.10 & 18.94 & 14.60 & 5.22 & 3.14 & 4.01 & 5.01 & 5.18 & 23.58 \\
\hline 1990 & 100.0 & 5.47 & 6.69 & 8.07 & 18.95 & 14.49 & 5.14 & 3.08 & 4.02 & 4.92 & 5.21 & 23.95 \\
\hline 1991 & 100.0 & 5.58 & 6.69 & 8.00 & 18.58 & 14.24 & 5.11 & 3.15 & 4.11 & 5.10 & 5.34 & 24.11 \\
\hline 1992 & 100.0 & 5.58 & 6.68 & 7.96 & 18.44 & 14.34 & 5.11 & 3.13 & 4.08 & 5.32 & 5.42 & 23.93 \\
\hline 1993 & 100.0 & 5.55 & 6.66 & 7.91 & 18.38 & 14.59 & 5.23 & 3.15 & 4.18 & 5.42 & 5.33 & 23.60 \\
\hline 1994 & 100.0 & 5.50 & 6.55 & 7.80 & 18.29 & 14.60 & 5.30 & 3.09 & 4.14 & 5.54 & 5.19 & 24.00 \\
\hline 1995 & 100.0 & 5.38 & 6.42 & 7.71 & 18.36 & 14.61 & 5.21 & 3.16 & 4.04 & 5.65 & 5.35 & 24.10 \\
\hline 1996 & 100.0 & 5.37 & 6.40 & 7.69 & 18.24 & 14.34 & 5.18 & 3.13 & 3.98 & 5.40 & 5.39 & 24.88 \\
\hline 1997 & 100.0 & 5.27 & 6.28 & 7.56 & 18.15 & 14.55 & 5.22 & 3.07 & 3.87 & 5.49 & 5.41 & 25.15 \\
\hline 1998 & 100.0 & 5.17 & 6.14 & 7.44 & 17.92 & 14.25 & 5.13 & 3.06 & 3.90 & 5.29 & 5.63 & 26.07 \\
\hline
\end{tabular}

Panel B: Percentage Distribution of Payroll

\begin{tabular}{|l|l|l|l|l|l|l|l|l|l|l|l|l|}
\hline 1988 & $100.0 \%$ & $5.85 \%$ & $5.54 \%$ & $7.01 \%$ & $16.99 \%$ & $13.16 \%$ & $4.83 \%$ & $2.95 \%$ & $3.95 \%$ & $5.27 \%$ & $5.88 \%$ & $28.55 \%$ \\
\hline 1989 & 100.0 & 5.65 & 5.43 & 6.87 & 16.72 & 13.27 & 4.99 & 3.17 & 4.21 & 5.58 & 6.00 & 28.10 \\
\hline 1990 & 100.0 & 5.55 & 5.42 & 6.87 & 16.75 & 13.28 & 4.90 & 3.10 & 4.22 & 5.39 & 6.12 & 28.40 \\
\hline 1991 & 100.0 & 5.51 & 5.44 & 6.83 & 16.41 & 13.03 & 4.99 & 3.19 & 4.34 & 5.60 & 6.28 & 28.37 \\
\hline 1992 & 100.0 & 5.48 & 5.39 & 6.73 & 16.24 & 13.12 & 5.02 & 3.21 & 4.34 & 6.03 & 6.43 & 28.01 \\
\hline 1993 & 100.0 & 5.46 & 5.38 & 6.73 & 16.29 & 13.38 & 5.13 & 3.22 & 4.49 & 6.06 & 6.47 & 27.38 \\
\hline 1994 & 100.0 & 5.41 & 5.29 & 6.69 & 16.40 & 13.49 & 5.18 & 3.16 & 4.39 & 6.30 & 6.23 & 27.45 \\
\hline 1995 & 100.0 & 5.31 & 5.14 & 6.58 & 16.39 & 13.54 & 5.13 & 3.23 & 4.27 & 6.49 & 6.45 & 27.47 \\
\hline 1996 & 100.0 & 5.29 & 5.08 & 6.51 & 16.33 & 13.48 & 5.13 & 3.21 & 4.19 & 6.24 & 6.53 & 28.01 \\
\hline 1997 & 100.0 & 5.20 & 4.95 & 6.36 & 16.23 & 13.73 & 5.13 & 3.24 & 4.15 & 6.27 & 6.68 & 28.06 \\
\hline 1998 & 100.0 & 5.09 & 4.83 & 6.26 & 16.05 & 13.49 & 5.04 & 3.15 & 4.12 & 5.98 & 6.72 & 29.29 \\
\hline
\end{tabular}

Source: Special tabulation by the Bureau of the Census 
Table 9: Gini Coefficients for Private-Sector Employment and Payroll, Relative to Numbers of Companies, 1988-1998

\begin{tabular}{|l|l|l|}
\hline Year & $\begin{array}{l}\text { Gini } \\
\text { Coefficient for } \\
\text { Employment }\end{array}$ & $\begin{array}{l}\text { Gini } \\
\text { Coefficient } \\
\text { for Payroll }\end{array}$ \\
\hline 1988 & 0.8262 & 0.8391 \\
\hline 1989 & 0.8290 & 0.8419 \\
\hline 1990 & 0.8290 & 0.8425 \\
\hline 1991 & 0.8304 & 0.8454 \\
\hline 1992 & 0.8314 & 0.8474 \\
\hline 1993 & 0.8323 & 0.8477 \\
\hline 1994 & 0.8347 & 0.8493 \\
\hline 1995 & 0.8359 & 0.8508 \\
\hline 1996 & 0.8372 & 0.8524 \\
\hline 1997 & 0.8388 & 0.8542 \\
\hline 1998 & 0.8414 & 0.8567 \\
\hline
\end{tabular}

Source: Computed by author, from data in Tables 7 and 8 
Table 10: Aggregate Concentration within Major Industry Sectors, as Measured by Share of Private-Sector Employment in Companies with More than 10,000 Employees, 1988-1998

\begin{tabular}{|c|c|c|c|c|c|c|c|c|c|c|}
\hline Year & & Mining & Constr. & Manuf. & $\begin{array}{l}\text { Trans., } \\
\text { Comm., Util. }\end{array}$ & Wholesale & Retail & Fin. \& R.E. & Services & Other \\
\hline \multirow[t]{2}{*}{1988} & \# of cos. & 9 & 4 & 210 & 65 & 21 & 124 & 78 & 120 & 2 \\
\hline & empl. \% & $17.2 \%$ & $1.5 \%$ & $31.4 \%$ & $41.3 \%$ & $6.8 \%$ & $28.1 \%$ & $24.8 \%$ & $10.4 \%$ & n.a. \\
\hline \multirow[t]{2}{*}{1989} & \# of cos. & 9 & 5 & 207 & 60 & 22 & 138 & 82 & 136 & 1 \\
\hline & empl. \% & $18.1 \%$ & $1.7 \%$ & $30.9 \%$ & $48.0 \%$ & $7.0 \%$ & $28.6 \%$ & $26.1 \%$ & $10.9 \%$ & n.a. \\
\hline \multirow[t]{2}{*}{1990} & \# of cos. & 9 & 4 & 208 & 64 & 24 & 146 & 79 & 151 & 1 \\
\hline & empl. \% & $17.5 \%$ & $1.7 \%$ & $30.6 \%$ & $40.7 \%$ & $7.4 \%$ & $29.3 \%$ & $26.4 \%$ & $11.5 \%$ & n.a. \\
\hline \multirow[t]{2}{*}{1991} & \# of cos. & 6 & 5 & 212 & 57 & 24 & 146 & 77 & 165 & 1 \\
\hline & empl. \% & $12.7 \%$ & $2.1 \%$ & $30.7 \%$ & $40.6 \%$ & $7.7 \%$ & $29.6 \%$ & $27.4 \%$ & $12.0 \%$ & n.a. \\
\hline \multirow[t]{2}{*}{1992} & \# of cos. & 7 & 4 & 204 & 56 & 22 & 151 & 67 & 172 & 2 \\
\hline & empl. \% & $13.8 \%$ & $1.9 \%$ & $29.6 \%$ & $39.8 \%$ & $7.5 \%$ & $30.3 \%$ & $26.5 \%$ & $12.2 \%$ & n.a. \\
\hline \multirow{2}{*}{1993} & \# of cos. & 3 & 5 & 200 & 59 & 25 & 156 & 71 & 190 & 1 \\
\hline & empl. \% & $5.4 \%$ & $1.9 \%$ & $28.4 \%$ & $39.8 \%$ & $7.6 \%$ & $30.8 \%$ & $26.6 \%$ & $12.8 \%$ & n.a. \\
\hline \multirow[t]{2}{*}{1994} & \# of cos. & 3 & 4 & 194 & 62 & 25 & 163 & 76 & 201 & 1 \\
\hline & empl. \% & $5.2 \%$ & $1.5 \%$ & $27.4 \%$ & $39.5 \%$ & $7.4 \%$ & $31.7 \%$ & $27.9 \%$ & $13.5 \%$ & n.a. \\
\hline \multirow[t]{2}{*}{1995} & \# of cos. & 2 & 3 & 200 & 58 & 25 & 169 & 75 & 205 & 2 \\
\hline & empl. \% & n.a. & $1.2 \%$ & $26.8 \%$ & $38.7 \%$ & $7.1 \%$ & $32.3 \%$ & $28.5 \%$ & $14.4 \%$ & n.a. \\
\hline \multirow[t]{2}{*}{1996} & \# of cos. & 1 & 2 & 199 & 63 & 26 & 171 & 80 & 230 & 2 \\
\hline & empl. \% & n.a. & n.a. & $26.4 \%$ & $40.1 \%$ & $7.2 \%$ & $33.0 \%$ & $30.4 \%$ & $15.9 \%$ & n.a. \\
\hline \multirow[t]{2}{*}{1997} & \# of cos. & 2 & 2 & 195 & 63 & 27 & 167 & 89 & 248 & 2 \\
\hline & empl. \% & n.a. & n.a. & $25.7 \%$ & $39.9 \%$ & $7.7 \%$ & $33.7 \%$ & $32.4 \%$ & $16.9 \%$ & n.a. \\
\hline \multirow[t]{2}{*}{$1998^{*}$} & \# of cos. & 2 & 3 & 154 & 77 & 20 & 117 & 92 & 328 & 0 \\
\hline & empl. \% & n.a. & $0.9 \%$ & $22.4 \%$ & $36.9 \%$ & $6.6 \%$ & $39.5 \%$ & $32.0 \%$ & $16.5 \%$ & 0 \\
\hline 1988 & $\begin{array}{l}\% \text { of all priv. } \\
\text { sec. empl. }\end{array}$ & $0.8 \%$ & $5.7 \%$ & $21.9 \%$ & $6.0 \%$ & $6.8 \%$ & $21.5 \%$ & $7.6 \%$ & $28.7 \%$ & $0.9 \%$ \\
\hline 1997 & $\begin{array}{l}\% \text { of all priv. } \\
\text { sec. empl. }\end{array}$ & $0.6 \%$ & $5.2 \%$ & $17.7 \%$ & $5.9 \%$ & $6.5 \%$ & $20.9 \%$ & $7.0 \%$ & $35.5 \%$ & $0.7 \%$ \\
\hline
\end{tabular}

*Because of the change from the SIC to NAICS industrial classification system in 1998, the 1998 data are not strictly comparable to earlier years, especially for "transportation, communications, and utilities" and for "services".

Source: Special tabulation by the Bureau of the Census. 

Table 11: Aggregate Concentration within Major Industry Sectors, as Measured by Share of Private-Sector Payroll in Companies with More than 10,000 Employees, 1988-1998

\begin{tabular}{|c|c|c|c|c|c|c|c|c|c|c|}
\hline Year & & Mining & Constr. & Manuf. & $\begin{array}{l}\text { Trans., } \\
\text { Comm., Util. }\end{array}$ & Wholesale & Retail & Fin. \& R.E. & Services & Other \\
\hline \multirow[t]{2}{*}{1988} & \# of cos. & 9 & 4 & 210 & 65 & 21 & 124 & 78 & 120 & 2 \\
\hline & payroll \% & $22.1 \%$ & $1.9 \%$ & $39.4 \%$ & $49.7 \%$ & $9.5 \%$ & $27.4 \%$ & $27.6 \%$ & $9.9 \%$ & n.a. \\
\hline \multirow[t]{2}{*}{1989} & \# of cos. & 9 & 5 & 207 & 60 & 22 & 138 & 82 & 136 & 1 \\
\hline & payroll \% & $22.5 \%$ & $2.3 \%$ & $39.2 \%$ & $48.0 \%$ & $10.1 \%$ & $28.4 \%$ & $29.3 \%$ & $10.6 \%$ & n.a. \\
\hline \multirow[t]{2}{*}{1990} & \# of cos. & 9 & 4 & 208 & 64 & 24 & 146 & 79 & 151 & 1 \\
\hline & payroll \% & $21.9 \%$ & $2.2 \%$ & $38.5 \%$ & $48.8 \%$ & $9.8 \%$ & $29.3 \%$ & $30.1 \%$ & $11.4 \%$ & n.a. \\
\hline \multirow[t]{2}{*}{1991} & \# of cos. & 6 & 5 & 212 & 57 & 24 & 146 & 77 & 165 & 1 \\
\hline & payroll \% & $15.4 \%$ & $2.6 \%$ & $38.7 \%$ & $47.7 \%$ & $10.0 \%$ & $29.6 \%$ & $30.9 \%$ & $12.0 \%$ & n.a. \\
\hline \multirow[t]{2}{*}{1992} & \# of cos. & 7 & 4 & 204 & 56 & 22 & 151 & 67 & 172 & 2 \\
\hline & payroll \% & $17.9 \%$ & $2.4 \%$ & $37.2 \%$ & $46.9 \%$ & $9.6 \%$ & $30.8 \%$ & $29.3 \%$ & $12.3 \%$ & n.a. \\
\hline \multirow[t]{2}{*}{1993} & \# of cos. & 3 & 5 & 200 & 59 & 25 & 156 & 71 & 190 & 1 \\
\hline & payroll \% & $6.5 \%$ & $2.2 \%$ & $36.0 \%$ & $47.1 \%$ & $9.8 \%$ & $31.1 \%$ & $29.0 \%$ & $13.1 \%$ & n.a. \\
\hline \multirow[t]{2}{*}{1994} & \# of cos. & 3 & 4 & 194 & 62 & 25 & 163 & 76 & 201 & 1 \\
\hline & payroll \% & $6.1 \%$ & $1.6 \%$ & $34.9 \%$ & $46.7 \%$ & $8.9 \%$ & $31.6 \%$ & $30.6 \%$ & $13.6 \%$ & n.a. \\
\hline \multirow[t]{2}{*}{1995} & \# of cos. & 2 & 3 & 200 & 58 & 25 & 169 & 75 & 205 & 2 \\
\hline & payroll \% & n.a & $1.3 \%$ & $34.1 \%$ & $46.0 \%$ & $8.5 \%$ & $32.5 \%$ & $31.2 \%$ & $14.6 \%$ & n.a. \\
\hline \multirow[t]{2}{*}{1996} & \# of cos. & 1 & 2 & 199 & 63 & 26 & 171 & 80 & 230 & 2 \\
\hline & payroll \% & n.a & n.a. & $33.5 \%$ & $46.5 \%$ & $8.3 \%$ & $33.0 \%$ & $32.8 \%$ & $16.2 \%$ & n.a. \\
\hline \multirow[t]{2}{*}{1997} & \# of cos. & 2 & 2 & 195 & 63 & 27 & 167 & 89 & 248 & 2 \\
\hline & payroll \% & n.a & n.a. & $32.8 \%$ & $46.3 \%$ & $8.7 \%$ & $33.1 \%$ & $35.0 \%$ & $17.1 \%$ & n.a. \\
\hline \multirow[t]{2}{*}{$1998^{*}$} & \# of cos. & 2 & 3 & 154 & 77 & 20 & 117 & 92 & 328 & 0 \\
\hline & payroll \% & n.a. & $0.8 \%$ & $27.7 \%$ & $37.1 \%$ & $7.5 \%$ & $32.1 \%$ & $35.0 \%$ & $21.4 \%$ & 0 \\
\hline 1988 & $\begin{array}{l}\% \text { of all priv. } \\
\text { sec. empl. }\end{array}$ & $0.8 \%$ & $5.7 \%$ & $21.9 \%$ & $6.0 \%$ & $6.8 \%$ & $21.5 \%$ & $7.6 \%$ & $28.7 \%$ & $0.9 \%$ \\
\hline 1997 & $\begin{array}{l}\% \text { of all priv. } \\
\text { sec. empl. }\end{array}$ & $0.6 \%$ & $5.2 \%$ & $17.7 \%$ & $5.9 \%$ & $6.5 \%$ & $20.9 \%$ & $7.0 \%$ & $35.5 \%$ & $0.7 \%$ \\
\hline
\end{tabular}

* Because of the change from the SIC to NAICS industrial classification system in 1998, the 1998 industry sector data are not strictly comparable to earlier years, especially for "transportation, communications, and utilities" and for "services".

Source: Special tabulation by the Bureau of the Census 

Table 12: Aggregate Concentration in the Entire Private Sector, as Measured by Corporate Profits and by Employment, 1980-2000

\begin{tabular}{|c|c|c|c|c|c|c|}
\hline & \multicolumn{2}{|l|}{ Forbes Data } & \multicolumn{2}{|c|}{ Private Sector Totals } & \multicolumn{2}{|c|}{ Large Co. Shares of Totals } \\
\hline Year & $\begin{array}{l}\text { Profits, Largest } \\
500 \text { Cos. } \\
\text { (\$ billion })\end{array}$ & $\begin{array}{l}\text { Employment } \\
\text { (million); No. } \\
\text { of Cos. }\end{array}$ & $\begin{array}{l}\text { Corp. Profits } \\
\text { (\$ billion) }\end{array}$ & $\begin{array}{l}\text { Employment } \\
\text { (million) }\end{array}$ & Profits & Employment \\
\hline 1980 & $\$ 119$ & $22.6(818)$ & $\$ 167$ & 74.2 & $71.3 \%$ & $21.2 \%$ \\
\hline 1981 & 124 & $22.4(798)$ & 157 & 75.2 & 79.0 & 20.9 \\
\hline 1982 & 112 & $21.6(808)$ & 109 & 73.7 & 102.8 & 20.5 \\
\hline 1983 & 132 & $21.9(808)$ & 136 & 74.3 & 97.1 & 20.7 \\
\hline 1984 & 140 & $21.2(785)$ & 171 & 78.4 & 81.9 & 19.2 \\
\hline 1985 & 133 & $21.1(798)$ & 179 & 81.0 & 74.3 & 18.5 \\
\hline 1986 & 141 & $20.6(790)$ & 198 & 82.7 & 71.2 & 17.8 \\
\hline 1987 & 156 & $20.5(796)$ & 244 & 84.9 & 63.9 & 17.2 \\
\hline 1988 & 167 & $19.9(778)$ & 321 & 87.8 & 52.0 & 16.2 \\
\hline 1989 & 182 & $20.3(783)$ & 293 & 90.1 & 62.1 & 16.2 \\
\hline 1990 & 171 & $20.6(776)$ & 275 & 91.1 & 62.2 & 16.1 \\
\hline 1991 & 155 & $20.8(790)$ & 252 & 89.8 & 61.5 & 16.4 \\
\hline 1992 & 179 & $20.4(774)$ & 300 & 90.0 & 59.7 & 16.0 \\
\hline 1993 & 204 & $20.2(785)$ & 375 & 91.9 & 54.4 & 15.6 \\
\hline 1994 & 250 & $20.2(776)$ & 441 & 95.0 & 56.7 & 15.2 \\
\hline 1995 & 285 & $20.4(787)$ & 558 & 97.9 & 51.1 & 14.9 \\
\hline 1996 & 325 & $20.9(785)$ & 635 & 100.2 & 51.2 & 15.0 \\
\hline 1997 & 356 & $21.9(779)$ & 731 & 103.1 & 48.7 & 15.4 \\
\hline 1998 & 364 & $22.9(799)$ & 909 & 106.0 & 40.0 & 15.7 \\
\hline 1999 & 451 & $23.9(895)$ & $773 *$ & 108.6 & 58.3 & 16.0 \\
\hline 2000 & 496 & $24.9(817)$ & $870 *$ & 111.1 & 57.0 & 16.3 \\
\hline
\end{tabular}

* Estimated; see text.

Sources: Forbes magazine; IRS; BLS. 